\title{
Antioxidant and Anti-Inflammatory Effects of Exercise in Diabetic Patients
}

\author{
Saeid Golbidi, Mohammad Badran, and Ismail Laher \\ Department of Pharmacology and Therapeutics, Faculty of Medicine, University of British Columbia, Vancouver, \\ BC, Canada V6T $1 Z 3$ \\ Correspondence should be addressed to Ismail Laher, ilaher@interchange.ubc.ca
}

Received 10 June 2011; Revised 15 July 2011; Accepted 17 July 2011

Academic Editor: Mark A. Yorek

Copyright ( $\odot 2012$ Saeid Golbidi et al. This is an open access article distributed under the Creative Commons Attribution License, which permits unrestricted use, distribution, and reproduction in any medium, provided the original work is properly cited.

Diabetes is a chronic metabolic disease which is characterized by absolute or relative deficiencies in insulin secretion and/or insulin action. The key roles of oxidative stress and inflammation in the progression of vascular complications of this disease are well recognized. Accumulating epidemiologic evidence confirms that physical inactivity is an independent risk factor for insulin resistance and type II diabetes. This paper briefly reviews the pathophysiological pathways associated with oxidative stress and inflammation in diabetes mellitus and then discusses the impact of exercise on these systems. In this regard, we discuss exercise induced activation of cellular antioxidant systems through "nuclear factor erythroid 2-related factor." We also discuss anti-inflammatory myokines, which are produced and released by contracting muscle fibers. Antiapoptotic, anti-inflammatory and chaperon effects of exercise-induced heat shock proteins are also reviewed.

\section{Introduction}

Diabetes is a chronic metabolic disorder that continues to be a major worldwide epidemic. The prevalence of diabetes has been growing rapidly from 135 million in 1995 to an estimated 380 million in 2025 [1]. This also has consequences on the management of diabetes related complications such as cardiovascular disease, nephropathy, retinopathy, and amputations. Physical inactivity and obesity are increasingly recognized as modifiable behavioral risk factors for a wide range of chronic diseases including diabetes mellitus. The advocacy of exercise as an interventional strategy against obesity, and related metabolic diseases gains added importance from the realization that restriction of calories without exercise can lower resting metabolic rate and prevent weight loss [2]. Indeed, several studies demonstrate that physical activity and exercise alone have multiple metabolic benefits such as improved insulin sensitivity, reduced glycated hemoglobin (HbAlc), and increased peak oxygen consumption $[3,4]$.

Physical activity and exercise are defined somewhat differently. Physical activity refers to "bodily movement produced by the contraction of skeletal muscle that requires energy expenditure in excess of resting energy expenditure." It can include a broad range of occupational, leisure, and daily activities [3]. Exercise is defined as "a subset of physical activity which are planned, structured and performed repetitively to improve or maintain one or more components of physical fitness" [5]. Exercise is classified by the type, intensity, and duration of activity. Endurance exercise reflects prolonged and continuous periods of contractile activity (high repetition) against low resistance whereas resistance exercise (strength training) involves short periods of contractile activity (low repetition) against a high opposing resistance. On the other hand, sprint exercise occurs during short periods of maximal (intense) repetitive contractile activity where there is a short period of exercise against a low resistance, such as running a $100 \mathrm{~m}$ sprint race. However, sprint training can also be performed against high resistance, which results in a combination of resistance and endurance modalities-for example, running with added weights. The terms physical activity and exercise will be used interchangeably in this paper.

Although there are clear benefits of exercise in diabetic patients, a detailed understanding of the molecular basis 
underlying these improvements remains incomplete. An increased understanding of the molecular basis for exerciseinduced metabolic effects is important in developing optimal exercise interventions for primary and secondary prophylaxis.

\section{Diabetes and Oxidative Stress}

A number of complications arise as a consequence of macroand microvascular complications that result from diabetes; these deficits have a central role in the tissue-damaging effects of chronic hyperglycemia [6]. Since endothelial cells (as well as renal mesangial and Schwann cells) are unable to limit glucose transport as well as other cells do, they are more vulnerable to the toxic effects of hyperglycemia. In fact, from a cardiovascular medicine perspective, diabetes can also be classified as a cardiovascular disease [7]. Several studies have shown that diabetes mellitus (types I and II) is accompanied by increased formation of free radicals and decreased antioxidant capacity, leading to oxidative damage of cell components [8]. There are multiple sources of reactive oxygen species (ROSs) production in diabetes including those of mitochondrial and nonmitochondrial origins; ROS accelerates the four important molecular mechanisms involved in hyperglycemia-induced oxidative tissue damage. These four pathways are activation of protein kinase $\mathrm{C}$ (PKC), increased hexosamine pathway flux, increased advanced glycation end product (AGE), and increased polyol pathway flux [9].

Almost ten years have elapsed since Brownlee's concept of the central role of mitochondrial superoxide production in the pathogenesis of diabetic complications [10]. Briefly, he stated that increased intracellular glucose leads to an abundance of electron donors generated during the Kreb's cycle, so driving the inner mitochondrial membrane potential upward - a state that is associated with mitochondrial dysfunction and increased ROS production. This superoxide production overwhelms the capacity of MnSOD to dismutase superoxide to $\mathrm{H}_{2} \mathrm{O}_{2}$. These reactive oxygen and nitrogen species trigger DNA single-strand breakage to induce a rapid activation of poly (ADP-ribose) polymerase (PARP), which in turn reduces the activity of glyceraldehyde-3-phosphate dehydrogenase (GAPDH) to increase all the glycolytic intermediates that are upstream of GAPDH (Figure 1). Increased amounts of glyceraldehyde-3 phosphate directly activate two of the four aforementioned pathways, it activates AGE and PKC pathways because methylglyoxal, which is the major intracellular AGE precursor, and diacylglycerol, which activates PKC, are formed from glyceraldehyde-3 phosphate. Another upstream metabolite, fructose- 6 phosphate, and also glucose, enter the hexosamine and polyol pathways, respectively. An increase in the hexosamine pathway leads to a greater production of UDP (uridine diphosphate) $\mathrm{N}$ acetylglucosamine, which often results in pathologic changes in gene expression such as increased expression of transforming growth factor $\beta 1$ and plasminogen activator inhibitor1. Increases in the polyol pathway leads to a consumption of NADPH, a cofactor that is required for the regeneration of reduced glutathione. Activated PKC has a number of effects on gene expression such as decreased expression of eNOS and increased expressions of endothelin, vascular endothelial growth factor, plasminogen activator inhibitor1 , transforming growth factor- $\beta, \mathrm{NAD}(\mathrm{P}) \mathrm{H}$ oxidases, and nuclear factor $\kappa \mathrm{B}(\mathrm{NF}-\kappa \mathrm{B})$, these in turn activate many proinflammatory genes in the vasculature. The activation of the AGE pathway can damage cells by three mechanisms: first, these compounds modify intracellular proteins, especially those involved in gene transcription regulation; second, these compound can diffuse to the extracellular space and modify extracellular proteins such as laminin and fibronectin to disturb signaling between the matrix and the cells; a finally, these compounds modify blood proteins such as albumin, causing them to bind to AGE receptors on macrophages/mesangial cells and increase the production of growth factors and proinflammatory cytokines [11]. The production of ROS is reduced by using either an uncoupler of oxidative phosphorylation or by the overexpression of either uncoupling protein-1 or MnSOD, such that normalizing the levels of mitochondrial ROS with any of these agents will prevent glucose-induced activation of protein kinase $\mathrm{C}$, formation of advanced glycation end products, sorbitol accumulation and NF- $\kappa \mathrm{B}$ activation [12]. These findings support the feasibility of targeting the triggering role of mitochondrial superoxide production in hyperglycemiainduced tissue damage.

Nonmitochondrial sources of ROS include: $\mathrm{NAD}(\mathrm{P}) \mathrm{H}$ oxidase, xanthine oxidase, uncoupled eNOS, lipoxygenase, cyclooxygenase, cytochrome $\mathrm{P} 450$ enzymes, and other hemoproteins [27]. The structure and function of $\mathrm{NAD}(\mathrm{P}) \mathrm{H}$ oxidase was first described in neutrophils, where its superoxide production causes bacterial destruction [28]. Later work confirmed $\mathrm{NAD}(\mathrm{P}) \mathrm{H}$ oxidase production of ROS in vascular smooth muscle [29], endothelial [30] and mesangial cells [31], platelets [32], and other cell types [33, 34]. Activation of $\mathrm{NAD}(\mathrm{P}) \mathrm{H}$ oxidase in phagocytic cells is very fast (seconds) and a large burst of superoxide is produced, while activation in nonphagocytic cells takes longer (minutes to hours) and superoxide is produced continually at lower rates [29, 35]. Common stimulators of vascular $\mathrm{NAD}(\mathrm{P}) \mathrm{H}$ are angiotensin II [36], thrombin [37], platelet-derived growth factor [38], and tumor necrosis factor- $\alpha$ [39]. Inhibition of NADPH oxidase-dependent production of ROS in diabetes by a variety of PKC inhibitors suggests a regulatory role of PKC in hyperglycemia induced NADPH oxidase activity [40]. In keeping with this, PKC inhibitors decrease the expression of NADPH oxidase in high glucose-treated endothelial cells [30]. Superoxide production measured in arteries and veins from diabetic and nondiabetic patients undergoing coronary artery bypass surgery confirm an enhanced $\mathrm{NAD}(\mathrm{P}) \mathrm{H}$ oxidase-mediated production of superoxide anions in diabetics, an effect that is abrogated by chelerythrine, an inhibitor of PKC [41].

Xanthine oxidase and xanthine dehydrogenase are collectively referred to as xanthine oxidoreductase. While both these enzymes catalyze the conversion of hypoxanthine to xanthine and then to uric acid, xanthine oxidase reduces oxygen as an electron acceptor while xanthine dehydrogenase 


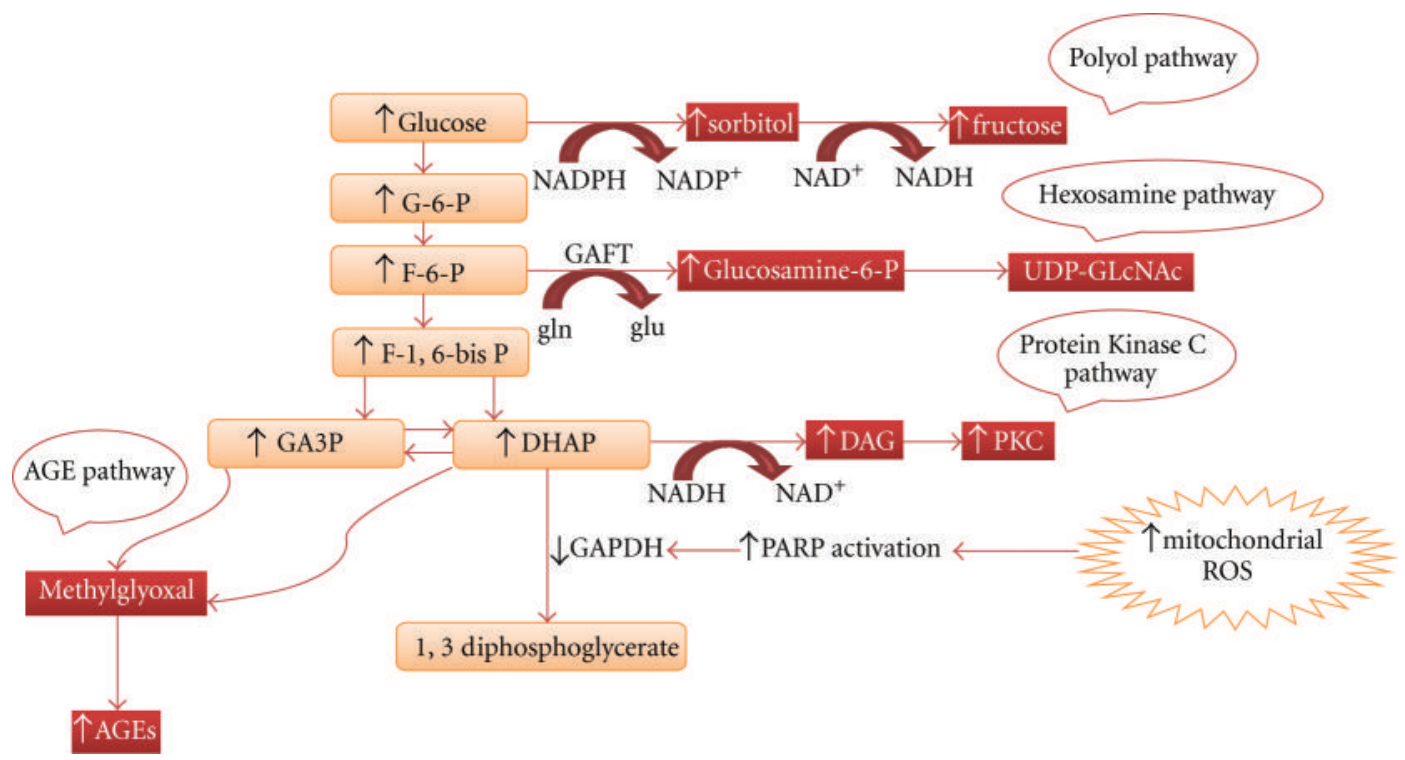

FIGURE 1: Mitochondrial ROS overproduction accelerates four hyperglycemia-induced tissue damage pathways. Dihydroxyacetone phosphate (DHAP), glutamate (glu), glutamine (gln), glutamine fructose-6-phosphate amidotransferase (GAFT), glyceraldehyde-3-phosphate dehydrogenase (GAPDH), poly (ADP-ribose) polymerase (PARP), and uridine diphosphate-N-acetylglucosamine (UDP-GLcNAc).

can reduce either oxygen or NAD+ [42]. Hydroxyl radicals, hydrogen peroxide, and superoxide are byproducts of xanthine oxidase. Even though there is some controversy about the presence of xanthine oxidase in normal endothelial cells $[43,44]$, it has been identified as a source of oxidative stress in the pathogenesis of atherosclerosis [45], ischemia-reperfusion [46], and diabetes mellitus [47, 48].

Nitric oxide is produced by inducible and constitutive nitric oxide synthases (NOSs), enzyme systems that incorporate oxygen into L-arginine. Constitutive eNOS contains reductase and oxygenase domains that are connected by a calmodulin-binding region and requires five cofactor groups (flavin adenine dinucleotide (FAD), flavin mononucleotide (FMN), heme, $\mathrm{BH}_{4}$, and $\mathrm{Ca}^{++}$-calmodulin) for activation. If eNOS lacks its substrate L-arginine or one of its cofactors, the enzyme will produce superoxide instead of nitric oxide and this is referred to as the uncoupled state of NOS. Furthermore, NO can react with superoxide to form peroxynitrite which in turn oxidizes $\mathrm{BH}_{4}$ and causes further uncoupling of NO formation [27].

Lipoxygenases are responsible for the conversion of arachidonic acid to leukotrienes and hydroxyeicosatetraenoic acids (HETEs) and lipoxins. They are classified according to their ability to insert molecular oxygen at the corresponding carbon position of arachidonic acid to 5-, 8-, 12-, or 15-lipoxygenase [49]. Reactive radicals, which are normally enzyme bound, are produced during the enzymatic reactions, but in some instances can also be released and attached to surrounding molecules. Lipoxygenase products, especially 12(S)-HETE and 15(S)-HETE, are involved in the pathogenesis of several diseases including diabetes where they have proatherogenic effects and mediate the actions of growth factors and proinflammatory cytokines [50, 51].
Cyclooxygenase (COX) enzymes catalyze the synthesis of various prostaglandins. The constitutive isoform COX1 is important under normal physiological conditions, while the inducible isoform COX2 is poorly expressed normally but increased dramatically during the inflammatory processes. These isoforms work in a coordinated fashion to help the body cope with diverse conditions. For example, COX2 expression is induced by proinflammatory cytokines through NADPH oxidase stimulation and ROS production. Elevated levels of glucose induce endothelium-derived vasoconstrictor prostanoids [52], suggesting a role for COX2 in diabetic vasculopathies. In addition, there is a significant correlation between plasma levels of hemoglobin $\mathrm{A} 1_{\mathrm{C}}$ and ligands of AGE receptors [53]. Further evidence supporting a role for oxidative stress in the induction of COX expression is that the expression of COX enzymes is normalized by glycemic control [53], and also by inhibition of oxidative phosphorylation, protein kinase $\mathrm{C}, \mathrm{NF} \kappa \mathrm{B}$ [54], or by mutation of the NF $\mathrm{NB}$ binding elements at the COX2 promoter site [55].

The cytochrome P450 monooxygenases are a large category of enzymes involved in the metabolism and detoxification of endogenous and exogenous materials. Dioxygen compounds, which decompose and release superoxide and hydrogen peroxide, are byproducts of this process $[56,57]$. Diabetes affects these different isoforms of the cytochrome P450 system; for example, there is an increased expression of CYP2E1 in type 1 and 2 diabetic $[58,59]$ and ob/ob mice [60], and also in STZ-induced diabetic rats [61]. The upregulation of hepatic CYP4A10 and CYP4A14 isoforms in ob/ob mice is thought to alleviate diabetes-induced hyperlipidemia since these enzymes are involved in fatty acid metabolism [62]. 


\section{Exercise and Antioxidant Capacity}

Cells have evolved highly complex enzymatic and nonenzymatic antioxidant systems which work synergistically, and in combination with each other, to protect the body against free radical-induced damage. The most efficient enzymatic antioxidants involve glutathione peroxidase, catalase, superoxide dismutase, heme oxygenase-1 (HO-1), NAD $(\mathrm{P}) \mathrm{H}$ quinone oxidoreductase-1 (NQO-1), and thioredoxin [63]. Non-enzymatic antioxidants include vitamins $\mathrm{E}$ and $\mathrm{C}$, thiol antioxidants (glutathione, thioredoxin) [64]. These antioxidants are capable of combining with reactive oxidants to produce other less reactive species. SOD promotes the dismutation of the superoxide radical to form hydrogen peroxide $\left(\mathrm{H}_{2} \mathrm{O}_{2}\right)$ and oxygen. Glutathione peroxidase ( $\left.\mathrm{GPx}\right)$ uses reduced glutathione $(\mathrm{GSH})$ as a reducing equivalent to reduce $\mathrm{H}_{2} \mathrm{O}_{2}$ to form oxidized glutathione and water. Catalase converts $\mathrm{H}_{2} \mathrm{O}_{2}$ to water and oxygen. Further, GSH can remove selected oxygen radicals directly and assist in the recycling of vitamins $\mathrm{C}$ and $\mathrm{E}$. The newly identified peroxiredoxin family is also a group of peroxidases that catalyze the reduction of $\mathrm{H}_{2} \mathrm{O}_{2}$ and so far at least six isoforms have been identified in mammalian cells [65]. Among them, peroxiredoxin III is synthesized with a mitochondrial targeting sequence (as is MnSOD) so that when it is transferred to mitochondria, its targeting residues are cleaved during maturation. Some studies suggest that peroxiredoxin III is a critical regulator of mitochondrial $\mathrm{H}_{2} \mathrm{O}_{2}$ concentrations, which promotes apoptosis in cooperation with other mediators of apoptotic signaling [66]. The specific localization of peroxiredoxin III within the mitochondria is thought to provide a primary line of defense against $\mathrm{H}_{2} \mathrm{O}_{2}$ produced by the mitochondrial respiratory chain [67].

Exercise training results in an upregulation of antioxidant defense mechanisms in various tissues, presumably due to increased levels of oxidative stress that occurs during exercise. Low/moderate amounts of ROS produced during regular skeletal muscle work are a part of "hormesis", which describes the generally favorable biological responses to low exposures to toxins and other stressors. A pollutant or toxin showing hormesis has opposite effects in small versus large doses. Hormesis is characterized by stimulation at low doses and inhibition at higher doses, resulting in an inverted U-shaped dose response effect [68]. For example, exercise-induced increased production of ROS can be beneficial by evoking specific adaptations, such as increased antioxidant/oxidative damage repairing enzyme activity, increased resistance to oxidative stress and lower levels of oxidative damage. On the other hand, excessive production of ROS is usually associated with detrimental effects.

Boosting of intrinsic antioxidant potential and reduction in lipid peroxidation occurs in healthy elderly men after habitual physical activity [69]. Physiological levels of shear stress increases the expression of $\mathrm{Cu} / \mathrm{Zn}$ SOD in human aortic endothelial cells [70], while endurance training mainly induces Mn-SOD expression [71]. In our experiments with $\mathrm{db} / \mathrm{db}$ mice, we observed a specific down-regulation of aortic Mn-SOD following diabetes. Low-intensity exercise increased $\mathrm{Cu} / \mathrm{Zn}-\mathrm{SOD}$ protein production, whereas moderate intensity exercise increased Mn-SOD [72]. Additional work is needed to clarify the importance and physiological roles of this preferential upregulation in SODs by exercise in diabetes.

A critical role has recently been described for a transcription factor "nuclear factor erythroid 2-related fatcor 2 (Nrf2)" against oxidative stress in health and during diabetes. Normally, Nrf2 is located in the cytoplasm and kept dormant by a cytoplasmic repressor named Kelch-like ECH-associated protein 1 (Keap1). A variety of activators, including oxidative free radicals, release and translocate Nrf2 into the nucleus where it regulates the expression of antioxidant enzymes such as NQO-1, glutathione s-transferase, glutathione peroxidase, and HO-1 [63] (Figure 2). Diminished Nrf2 activity contributes to increased oxidative stress and mitochondrial dysfunction in the vasculature leading to endothelial dysfunction, insulin resistance, and abnormal angiogenesis as observed in diabetics [73]. HO-1, which is mainly induced through the Nrf2-keap1 signaling pathway (also known as heat shock protein 32 ), is the inducible isoform of heme oxygenase that catalyzes the NADPH-dependent decomposition of heme to carbon monoxide (CO), ferrous iron, and biliverdin [74]. Three isoforms of $\mathrm{HO}$ have been identified: both $\mathrm{HO}-2$ and $\mathrm{HO}-3$ are $33-\mathrm{kDa}$ isoforms that are expressed constitutively [75]. The important role of HO- 1 in the antioxidant defense system arises from an induction of ferritin synthesis that diminishes the cellular pool of free iron [76] and also from the enhancement of bilirubin levels, which are potent antioxidants [77]. Carbon monoxide activates soluble guanylate cyclase, a key enzyme in cell signaling that leads to vasodilation, relaxation of smooth muscle, and thrombocyte disaggregation. Carbon monoxide also affects cellular metabolism and counteracts pro-inflammatory cytokine cascades [75]. HO-1 has been widely recognized as a sensitive and reliable marker of oxidative stress [78]. Niess et al. [79] demonstrated increased cytoplasmic expression of HO-1 in human leukocytes of endurance-trained male subjects after a half-marathon run. Additionally, they determined cytoplasmic HO-1 in a control group of untrained men at rest and showed a higher expression of $\mathrm{HO}-1$ compared to the athletes. They concluded that the down regulation of the baseline expression of HO- 1 in athletes reflects an adaptation mechanism to regular exercise training [79]. The direct effect of exercise on $\mathrm{Nrf} 2$ expression has received much less attention except for a report that exercise increases nuclear levels of $\mathrm{Nrf} 2$ in the proximal renal tubules of old rats [80].

The effects of exercise on myocardial antioxidant enzyme activities have been widely investigated. It is generally believed that even short-term endurance exercise training results in rapid increases in myocardial Mn-SOD activity, which greatly impacts ischemic/reperfusion injury [81-83]. Exercise also increases glutathione peroxidase activity in the liver, kidney, and heart [84] as well as in skeletal muscle [85]. Exercise, and hence changes in fluid shear stress, activates vascular NADPH oxidase and P22 $2^{\text {phox }}$ expression [86]. It is 

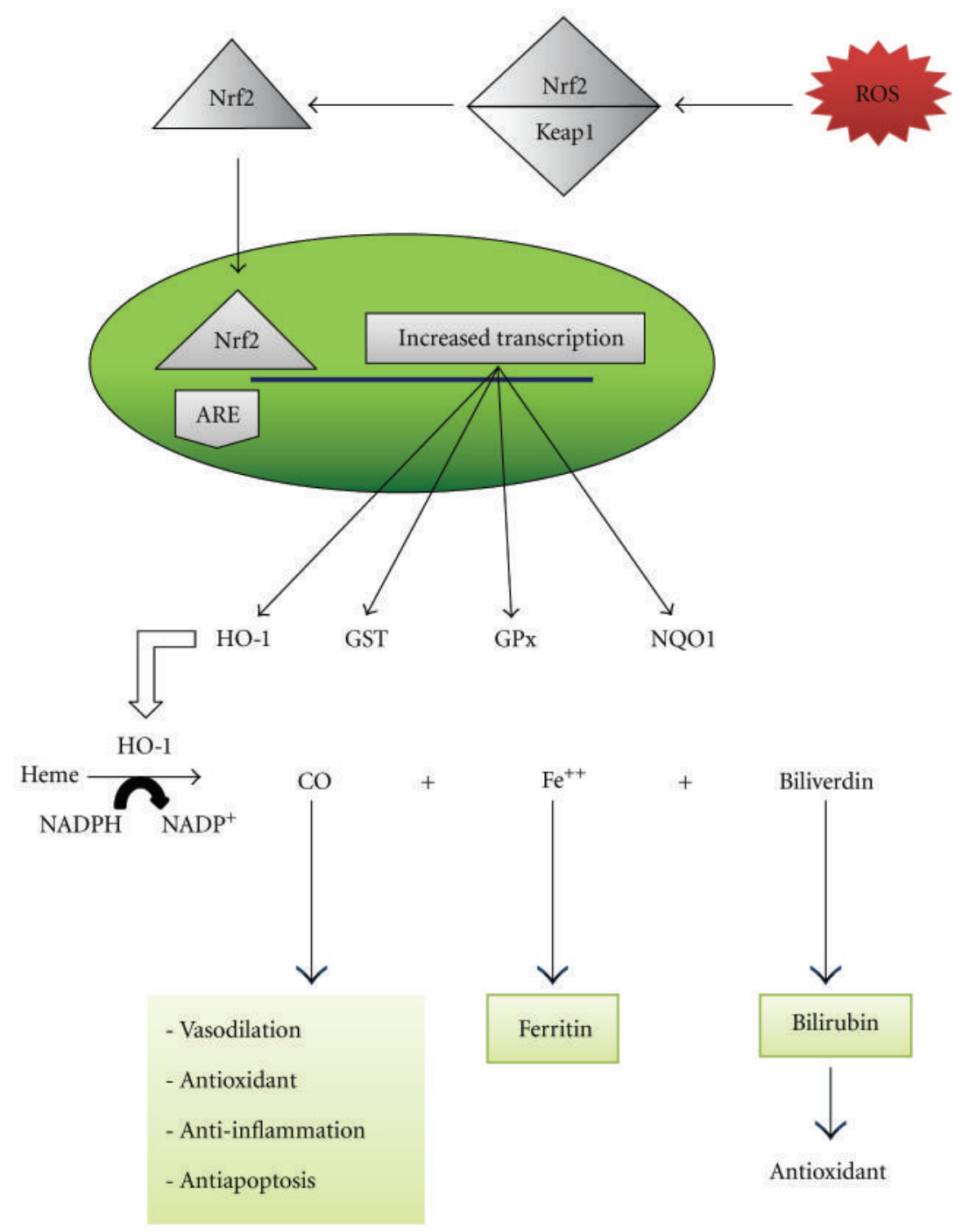

Figure 2: Exercise-induced ROS activates Nrf2, which then translocates into the nucleus to increase the expression of antioxidant enzymes. Antioxidant response element (ARE), carbon monoxide (CO), Glutathione peroxidase (GPx), Glutathione S-transferase (GST), Heme oxygenase-1 (HO-1), Kelch-like ECH-associated protein 1 (Keap1), NAD(P)H quinone oxidoreductase-1 (NQO-1), and nuclear factor erythroid 2-related factor 2 (Nrf2).

likely that $\mathrm{p} 22^{\text {phox }}$ affects NADPH oxidase in response to shear stress, which may in turn regulate the amount of vascular antioxidant enzyme gene expression levels [87].

\section{Diabetes, Inflammation, and Anti-Inflammatory Effect of Exercise}

Inflammation has a prominent role in the pathogenesis of several cardiovascular diseases. Atherosclerosis is an inflammatory disease that is mediated by monocyte derived macrophages which accumulate in arterial plaques and become activated to release cytokines that cause tissue damage [88]. Atherosclerotic plaques in type II diabetic patients have increased inflammatory properties and worse cardiovascular outcomes than plaques observed in non-diabetic subjects [89]. We reported that systemic inflammation precedes either hyperglycemia or oxidative stress in $\mathrm{db} / \mathrm{db}$ mice [90]. As evidence accumulates favoring the role of inflammation during the different phases of atherosclerosis, it is likely that markers of inflammation such as high-sensitivity C-reactive protein (hs-CRP) may be increasingly used to provide additional insights on the biological status of atherosclerotic lesions. Several studies have shown that CRP and proinflammatory cytokines, including interleukin-6 (IL6 ) and tumor necrosis- $\alpha$ (TNF- $\alpha$ ), are elevated in type II diabetic patients $[89,91]$. CRP is considered to be an inde- 
pendent predictor of cardiovascular events and of the outcome of acute coronary syndromes [92]. Diabetic patients can be grouped as being at low, intermediate, and high risk for cardiovascular disease based on their levels of hs-CRP [93]. Besides its role as a marker of systemic inflammation and a predictor of cardiovascular risk, CRP and other inflammatory cytokines also directly trigger vascular dysfunction [94], possibly via altering calcium channel expression and activity [95], upregulation of Rho-kinase expression and function [96], increasing the production of ROS [97], and/or enhancing cyclooxygenase expression [98]. In turn, cyclooxygenase enzymes cause vascular hypercontractility by increasing the synthesis of constrictor prostanoid(s) [99, 100] and excessive formation of ROS [101]. Cyclooxygenase inhibitors alleviate the augmented contractile responses in several animal models of diabetes [102-106]. These findings may partially explain the inconsistent and mostly disappointing results with antioxidant use in diabetic patients [64], since inflammation rather than oxidative stress may be the principle contributor to diabetic vascular dysfunction. In agreement with this concept is the finding that endothelial function improves in type 2 diabetic patients treated with rosiglitazone, an agent that reduces inflammation but not oxidative stress [107].

Exercise produces a short-term inflammatory response that is accompanied by leukocytosis, increases in oxidative stress, and plasma levels of CRP. This pro-inflammatory response is followed by a long term anti-inflammatory effect [108]. Regular exercise reduces CRP, IL-6, and TNF$\alpha$ levels and also increases anti-inflammatory substances such as IL-4 and IL-10 [109, 110]. In healthy young adults, a 12-week, high-intensity aerobic training program down regulates cytokine release from monocytes [110]. In fact, even leisure time physical activity (e.g., walking, jogging, or running, etc.) reduces hs-CRP concentration in a graded manner [111]. Table 1 summarizes the findings of clinical studies on the effects of exercise on anti-inflammatory and antioxidant markers in diabetic patients.

\section{Myokines as Anti-Inflammatory Agents}

Pedersen and colleagues [112-116] suggest that just as adipose tissue is recognized as an endocrine organ, skeletal muscle should also be considered as an endocrine tissue. The term "myokines" was later coined for cytokines and other peptides that are produced, expressed, and released by muscle fibers. The list of myokines includes IL-6, IL-8, IL15 , brain-derived neurotrophic factor, leukemia inhibitory factor plus fibroblast growth factor-21, and follistatin like1 [113]. They are released from working muscles into the circulation where they exert their effects on other organs in a hormone-like fashion. Myokines are thought to mediate the beneficial effects of exercise and may also have a role in the protection against diseases associated with low-grade inflammation such as atherosclerosis, type II diabetes, or the metabolic syndrome.

IL-6 is the first cytokine released into the circulation during exercise and its levels increase in an exponential fashion in response to exercise (99). IL-6 mRNA is upregulated in contracting skeletal muscle [117] and the transcriptional rate of the IL- 6 gene is also markedly enhanced by exercise [118]. IL-6 acts as both a proinflammatory and anti-inflammatory cytokine. When secreted by $\mathrm{T}$ cells and macrophages, IL-6 stimulates immune responses and boosts inflammatory reactions, while muscle-produced IL-6 exerts anti-inflammatory effects through its inhibitory effects on TNF- $\alpha$ and IL- $1 \beta$, and activation of IL-1ra and IL-10 [115]. Exercise-induced increases in plasma IL- 6 correlate with the muscle mass involved in exercise activity and also with the mode, duration, and especially intensity of exercise [119]. Exercise also confers protection against TNF-induced insulin resistance [120]. In addition, Starkie et al. reported that infusion of recombinant human IL-6 (rhIL-6) into human subjects simulated the exercise induced IL- 6 response in the prevention of endotoxin-induced increase in plasma TNF$\alpha$ [121]. Exercise can also suppress TNF- $\alpha$ production by an IL-6 independent pathway, as demonstrated by Keller et al. who reported only modest decreases in plasma TNF$\alpha$ after exercise in IL-6 knockout mice [122]. Exercise induced increases in epinephrine levels can also blunt the TNF- $\alpha$ response [123]. In addition, Petersen et al. showed that IL-6 enhances lipid turnover and stimulates lipolysis as well as fat oxidation via activation of AMP-activated protein kinase [124]. Consistent with this, Wallenius et al. demonstrated that IL-6 deficient mice (IL6-/-) develop mature onset obesity and have disturbed carbohydrate and lipid metabolism that is partly reversed by IL- 6 replacement. Other data indicates that centrally acting IL-6 exerts an antiobesity effect in rodents [125]. The lipolytic effect of IL6 on fat metabolism was confirmed in two clinical studies of healthy and diabetic subjects $[124,126]$. Visceral fat is potentially a cause of low-grade systemic inflammation, which in turn leads to insulin resistance, type II diabetes, and atherosclerosis [113]. During exercise, IL-6 also increases hepatic glucose production. Glucose ingestion during exercise reduces IL- 6 production by muscles, suggesting that IL-6 is released due to of the reduction in glycogen levels during endurance exercise and the consequent adrenergic stimulation of IL-6 gene transcription via protein kinase A activation [127].

\section{Heat Shock Proteins}

There is widespread clinical interest in the role of heat shock proteins (HSPs) in a number of human diseases, including diabetes. The heat shock response is a common cellular reaction to external stimuli such as ischemia [128], hypoxia [129], acidosis [130], oxidative stress [131], protein degradation [132], increased intracellular calcium [133], and energy depletion [134]. Therefore, the terms "stress proteins" and "cellular stress response" reflect the array of stressors known to initiate HSP expression [135]. Heat shock proteins are grouped into six major families based on their molecular weight and related functions, that is, $110 \mathrm{kDa}$ HSPs, $90 \mathrm{kDa}$ HSPs, $70 \mathrm{kDa}$ HSPs, $60 \mathrm{kDa}$ HSPs, $40 \mathrm{kDa}$ HSPs, and small HSPs such as HSP27, $\alpha \mathrm{B}$-crystallin, and ubiquitin. Some HSPs are constitutively expressed in 
TABLE 1: Summary of clinical studies on the anti-inflammatory and antioxidant effects of exercise in diabetic patients reported during the last 10 years.

\begin{tabular}{|c|c|c|c|c|}
\hline Reference & Patient characteristics & Exercise duration & Measured parameters & Outcome \\
\hline [13] & $\begin{array}{l}14 \text { T2D versus } 12 \text { healthy } \\
\text { subjects }\end{array}$ & 18 weeks & $\begin{array}{l}\text { (i) Ability of HDL subfractions } \\
\text { to inhibit LDL oxidation in vitro. } \\
\text { (ii) Serum PON activity. } \\
\text { (iii) Total antioxidant status. } \\
\text { (iv) Plasma lipid peroxidation. }\end{array}$ & $\begin{array}{l}\text { (i) Exercise improved the } \\
\text { antioxidant role of HDL and } \\
\text { reduced plasma lipid peroxidation } \\
\text { in diabetic subjects. }\end{array}$ \\
\hline$[14]$ & $\begin{array}{l}50 \text { T2D versus } 20 \text { age matched } \\
\text { controls }\end{array}$ & $\begin{array}{l}\text { Single bout (exercise } \\
\text { cycle ergometer test) }\end{array}$ & $\begin{array}{l}\text { (i) TG, TC, LDL, oxLDL, SOD, } \\
\text { GSH-Px, PAI. }\end{array}$ & $\begin{array}{l}\text { (i) Exercise increased oxLDL and } \\
\text { SOD in both groups; GSH-Px was } \\
\text { increased only in diabetic patients. }\end{array}$ \\
\hline [15] & 13 diabetic men & $\begin{array}{l}3 \text { weeks combination } \\
\text { of high-fiber, low-fat } \\
\text { diet plus aerobic } \\
\text { exercise }\end{array}$ & $\begin{array}{l}\text { (i) Serum lipids, glucose, insulin, } \\
\text { 8-iso-PGF2 } \alpha \text {, CRP, sICAM-1, } \\
\text { sE-selectin } \\
\text { (ii) in vitro measurement of NO, } \\
\text { superoxide, and } \mathrm{H}_{2} \mathrm{O}_{2} \\
\text { (iii) Serum-induced monocyte } \\
\text { adhesion, ICAM-1, VCAM-1, } \\
\text { MCP- } 1 \text { in cultured endothelial } \\
\text { cells. }\end{array}$ & $\begin{array}{l}\text { (i) Reduction in TC, LDL, FSG, } \\
\text { insulin, } 8 \text {-iso-PGF2 } \alpha \text {, CRP, } \\
\text { sICAM-1, sE-selectin, serum } \\
\text { stimulated monocyte adhesion, } \\
\text { cellular ICAM- } 1 \text { and VCAM-1, } \\
\text { superoxide and } \mathrm{H}_{2} \mathrm{O}_{2} \text { and increase } \\
\text { in NO production. }\end{array}$ \\
\hline
\end{tabular}

134 T2D divided into 3 groups
(i) 43 , aerobic training plus

[16] using fitness center

(ii) 44 aerobic training only

(iii) 16 controls

[17]

16 T2D with diet restriction and 13 T2D with diet 12 weeks restriction and exercise
12 months

wans

\section{(i) Urinary 8-OHdG}

(ii) serum glycated albumin, TC, (i) Urinary 8-OHdG decrease after HDL, TG, HbAlc. 12 months in the exercise groups. (i) MDA, 24 h urinary nitrate/nitrite, FMD

(ii) BW, waist circumference, BP, HbAlc, glucose, insulin resistance, lipid profile. (i) Both interventions reduced BW, waist circumference, BP, HbA1c, glucose, insulin resistance, lipids and MDA, and increased urinary nitrite/nitrate ratio

(ii) No change in FMD.

(i) Significant reductions in FBS, (i) FBS, TC, TG, LDL, VLDL, HDL, MDA, POX, PLA2, SOD,

TC, VLDL, MDA

(ii) SOD increased.

(iii) No significant changes in PLA2 (i) $77 \mathrm{~T} 2 \mathrm{D}$ in yoga group

[18] exercise group (iii) $77 \mathrm{~T} 2 \mathrm{D}$ as controls catalase activity.

6 months

catalase activity.
and catalase activity.

(i) BMI, serum lipids, MDA, and CRP significant improved in TCE group. HbA1c did not decrease. (ii) No improvement in BMI, lipids, and oxidative stress profiles in the CE group.

(i) T2DS had higher FBS, HbA1c, and body fat percent than T2SA.

(ii) T2DA had higher $\mathrm{VO}_{2 \max }$ spent

(i) 12 sedentary nondiabetes subjects (ND)

[20] (ii) 12 sedentary T2D (T2S)

(iii) 9 physically active (T2DA)
Single bout of intense exercise $(>85 \%$ $\left.\mathrm{VO}_{2 \max }\right)$ CRP

(ii) BW, BMI. more time on treadmill, lower $\mathrm{Hb}$ and BP compared with ND and T2DS.

(iii) TBARS in T2DS were higher than T2DA.

(iv) GSH was similar among groups.

(i) Muscle strength and Wmax increased.

(i) Muscle strength, Wmax, $\mathrm{VO}_{2 \max }$, MUOX, IMCL and IMCG, systemic inflammatory markers and primary diabetic outcome measures plus daily exogenous insulin requirements (EIRs). (ii) Mean arterial BP and EIR, FBG and nonesterified fatty acids declined.

(iii) No changes in $\mathrm{VO}_{2 \max }$, MUOX, IMCL or IMCG, HbA1c, adiponectin, TNF- $\alpha$, and cholesterol. 
TABLE 1: Continued.

\begin{tabular}{|c|c|c|c|c|}
\hline Reference & Patient characteristics & Exercise duration & Measured parameters & Outcome \\
\hline$[22]$ & $\begin{array}{l}20 \text { T2D (sedentary control, A) } \\
20 \text { T2D (low intensity aerobic } \\
\text { exercise, B) } \\
20 \text { T2D (high intensity aerobic } \\
\text { exercise, C) } \\
22 \text { T2D (aerobic and } \\
\text { resistance exercise, D) }\end{array}$ & 12 months & $\begin{array}{l}\text { HbAlc, FBS, TG, TC, HDL, } \\
\text { hs-CRP, IL- } 1 \beta \text {, IL- } 4 \text {, IL- } 6 \text {, IL-10, } \\
\text { TNF- } \alpha \text {, IFN- } \gamma \text {, leptin, resistin, } \\
\text { adiponectin } \mathrm{VO}_{2 \max }\end{array}$ & $\begin{array}{l}\text { (i) Significant decrease of hs-CRP in } \\
\text { groups C and D. } \\
\text { (ii) leptin, resistin, IL- } 6 \text { decreased } \\
\text { in groups C\&D, while adiponectin } \\
\text { increased. } \\
\text { (iii) IL- } 1 \beta \text {, TNF- } \alpha \text {, IFN- } \gamma \text { decreased } \\
\text { in group D, whereas } \\
\text { anti-inflammatory IL- } 4 \text { \& } 10 \text { levels } \\
\text { declined. }\end{array}$ \\
\hline$[23]$ & $\begin{array}{l}406 \text { T2D out of } 522 \\
\text { participants from the Finnish } \\
\text { Diabetes Prevention Study }\end{array}$ & 1 year & CRP and IL-6 levels. & $\begin{array}{l}\text { (i) Increases in fiberintake and } \\
\text { moderate to vigorous leisure time } \\
\text { physicalactivity (LTPA), but not } \\
\text { total LTPA, predicted decreases } \\
\text { inCRP and/or IL-6. }\end{array}$ \\
\hline$[24]$ & $\begin{array}{l}15 \text { T2D (control) } \\
15 \text { T2D (10000 steps/day) }\end{array}$ & 6 weeks & $\begin{array}{l}\text { (i) Anthropometric measures } \\
\text { plus, HbA1c, FBS, insulin, lipid } \\
\text { profile, fructosamine, total } \\
\text { radical antioxidant parameter, } \\
\text { PAI-1, homocysteine and } \\
\text { lipoprotein(a). }\end{array}$ & $\begin{array}{l}\text { (i) HDL and resting energy } \\
\text { expenditure increased while PAI-1 } \\
\text { levels decreased in the active group. }\end{array}$ \\
\hline$[25]$ & $\begin{array}{l}25 \text { T2D (exercise group) } \\
25 \text { T2D (control group) }\end{array}$ & 16 weeks & $\begin{array}{l}\text { (i) Anthropometric measures } \\
\text { and insulin resistance, MMP-2, } \\
\text { TIMP-1, lipid profile, } \mathrm{HbAlc} \\
\text { fibrinogen, hsCRP, } \mathrm{VO}_{2 \max }, \mathrm{VT} \text {. }\end{array}$ & $\begin{array}{l}\text { (i) Systolic and mean BP, LDL, } \\
\text { HbA1c, fibrinogen, hsCRP, MMP-9 } \\
\text { and MMP-9 to TIMP-1 ratio } \\
\text { decreased in exercise group while } \\
\mathrm{VO}_{2 \text { max }} \text {, VT and plasma TIMP-2 } \\
\text { levels increased. }\end{array}$ \\
\hline$[26]$ & $\begin{array}{l}60 \text { patients with IGTT: } \\
24 \text { in exercise training group } \\
20 \text { in rosiglitazone group } \\
16 \text { in control group }\end{array}$ & 12 months & $\begin{array}{l}\text { (i) Genotyping of the } 174 \mathrm{G} / \mathrm{C} \\
\text { IL- } 6 \text { variant. } \\
\text { (ii) CRP and IL- } 6 \text { measurements. }\end{array}$ & $\begin{array}{l}\text { (i) Improved peak } \mathrm{VO}_{2 \max } \text {, } \\
\text { decreases in BMI, WHR, HbA1c, } \\
\text { plasma glucose and insulin, 2-h } \\
\text { OGTT glucose level IL-6 and } \\
\text { hsCRP in exercise group. }\end{array}$ \\
\hline
\end{tabular}

Abbreviations: 8-OHdg: 8-hydroxy-2'-deoxyguanosine, BMI: body mass index, BP: blood pressure, BW: body weight, CRP: C reactive protein, FBS: fasting blood sugar, FMD: flow mediated dilatation, GSH: glutathione, GSH-Px: glutathione peroxidase, HbAlc: hemoglobin A $\mathrm{A}_{1 \mathrm{c}}$, HDL: high density lipoproteins, ICAM-1: intracellular adhesion molecule-1, IFN: interferon, IL: interleukin, IMCG: intramyocellular glycogen, IMCL: intramyocellular lipid, LDL: low density lipoprotein, MCP-1: monocyte chemotactic protein-1, MDA: malondialdehyde, MMPs: matrix metalloproteinases, MUOX: muscle oxidative capacity, oxLDL: oxidized low density lipoproteins, PAI: plasminogen activator inhibitor, PLA2: phospholipase A2, PON: paraoxonase, POX: protein oxidation, sICAM: soluble intracellular adhesion molecule, SOD: superoxide dismutase, T2D: type II diabetes, TBARS: thiobarbituric acid substances, TC: total cholesterol, TG: triglyceride, TIMPs: tissue inhibitor of metalloproteinases, VCAM-1: vascular cell adhesion molecule-1, VLDL: very low density lipoprotein, $\mathrm{VO}_{2 \text { max }}$ : whole body peak oxygen uptake, VT: ventilatory threshold, and Wmax: maximal workload capacity.

cells (e.g., HSP90, HSP70), while other HSPs are rapidly and highly inducible in response to stress (e.g., HSP70, HSP27) $[136,137]$. Several important cytoprotective functions have been attributed to these proteins including (a) folding of proteins in various intracellular compartments, (b) maintenance of structural proteins, (c) refolding of misfolded proteins, (d) translocation of proteins across membranes into various cellular compartments, (e) prevention of protein aggregation, (f) degradation of unstable proteins, and (g) apoptosis [137]. An increased content of HSPs promotes cellular recovery by binding with misfolded and unfolded proteins and promoting the refolding of these proteins when cellular conditions improve [138]. Thus, an important role for the increased expression of HSPs is to function as molecular chaperones, having the features of a feedback system that reacts to increased misfolded proteins by elevating the synthesis of the chaperones that helps in the refolding process [139]. HSPs also have roles as antioxidants and in the inhibition of apoptosis and inflammation [140]. Levels of HSP72 mRNA in skeletal muscle decrease in patients with type II diabetes and this may be related with insulin resistance [141-143]. Studies in animals show that heat shock therapy, regardless of the way used to achieve HSP elevation (transgenic overexpression or pharmacologic means to overexpress HSP72 protein expression), protects against diet- or obesity-induced hyperglycemia, hyperinsulinemia, glucose intolerance, and insulin resistance [144]. Suggested mechanisms for the reduction of HSPs in diabetes include the following: insulin has regulatory roles in both the initiation and elongation phases of translation by altering the phosphorylation of eukaryotic translation initiation factors and eukaryotic elongation factors, therefore its impaired or deficient secretion in diabetes may be one explanation for attenuated (stress) protein synthesis [142]. Suppression of heat shock transcription factor-1 (HSF-1) via upregulation of glycogen synthase kinase, an enzyme 
originally described as a regulator of glycogen metabolism [143]. The reduced HSF-1 and HSP levels in diabetes could result from decreased membrane fluidity and compromised membrane integrity. Vigh et al. considered how the physical state of the membrane could affect gene expression and, hence, responses to stress: they proposed that alterations in plasma membrane microdomains are well suited for sensing stress and retailoring the expression of the various classes of HSPs [145]. Some pathological conditions, including diabetes, which are associated with membrane defects, can be improved with insulin therapy [146].

Prolonged exercise of sufficiently high intensity creates physiological stresses and disturbs cellular homeostasis, leading to induction of cellular adaptation mechanisms. There is an increased HSP70 mRNA concentration after just 4 min of a single bout of exercise at anaerobic threshold in human subjects [44]. In another study in humans, Walsh et al. [147] demonstrated increased HSP72 mRNA expression in skeletal muscles 2 hours after exercise and increased serum HSP72 protein. The increase in serum HSP72 preceded any increase in HSP72 gene or protein expression in contracting muscle, suggesting that HSP72 was released from other tissues or organs, suggesting a systemic role for the protein. Although increased muscular HSP transcription occurs during exercise, immediately after exercise or several hours after it, a brisk increase in protein content is only detectable after 1-2 days following the exercise stress [139].

\section{Activation of HSPs in Skeletal Muscles}

The redox-signaling pathway is the main mechanism for induction of the stress response during endurance exercise. Thus, Fischer et al. [148] reported that a combination of vitamin $\mathrm{C}$ and $\mathrm{E}$ for 28 days prevented increases in muscle HSP27 mRNA expression as well as circulating levels of HSP72 protein. This finding is supported by data from other investigators who also reported that the increased HSP70 content in human skeletal muscle following exercise was abolished by antioxidant therapy [149, 150]. Antioxidant therapy scavenges exercise induced ROS, thereby abolishing transcriptional activity of the HSP gene [139]. It is also likely that antioxidants increase baseline muscle HSP70 content, so explaining the diminished response during stress $[149,150]$. In addition to aerobic exercise protocols, several studies have used resistance exercise and downhill running protocols to study HSP expression in human muscle $[151,152]$. These protocols are considered more damaging since they induce overt structural and mechanical damage to the muscles. Increases in HSP27, HSP70, and $\alpha \mathrm{B}$-crystallin have also been reported in these studies. It is difficult to compare the results of these studies with those using nondamaging exercise protocols, since data from damaging exercise protocols are complicated by inflammatory responses; for example, phagocyte cells, which infiltrate 2-3 days after damaging exercise, contain relatively high levels of HSP, and neutrophils are also sources of superoxide that can induce HSP production.

\section{Antiapoptotic and Anti-Inflammatory Effects of HSPs}

The HSP70 family is the most abundant HSP and mostly includes the constitutive cytosolic HSP73 and the stressinduced cytosolic HSP72. In addition to their chaperone functions, some beneficial effects are attributed to their antiapoptotic and anti-inflammatory effects. Apoptosis, the process of programmed cell death that occurs in multicel-lular organisms, can originate either extracellularly (by acti-vation of specific death receptors) or intracellularly [153]. Mitochondria play an important role in the regulation of apoptosis. They contain several proapoptotic proteins such as cytochrome C, apoptosis inducing factor (AIF), and second mitochondria-derived activator of caspases (SMACs). These factors are released from the mitochondria following the formation of a pore in the mitochondrial membrane called the permeability transition pore, or PTP. These pores are thought to result from apoptotic signals such as cell stress, free radical damage, or growth factor deprivation [154]. Once cytochrome $\mathrm{C}$ is released, it binds with apoptotic protease activating factor-1 (Apaf-1) and ATP, which then bind to procaspase- 9 to create a protein complex known as an apoptosome. The apoptosome cleaves the procaspase to its active form of caspase-9, which in turn activates the effector caspase-3. Upon release of SMAC, it binds to inhibitor of apoptosis proteins (IAPs) and deactivates them, preventing the IAPs from arresting the apoptotic process and therefore allowing apoptosis to continue. IAPs normally suppress the activity of caspases, which carry out the degradation of the cell. When AIF is released from mitochondria, translocates to the nucleus, where apoptosis occurs in the absence of caspase activation (caspase-independent pathways) [155]. Mitochondrial release of cytochrome $\mathrm{C}$ and AIF can be antagonized by bcl-2. The bcl-2 proteins are a family of proteins involved in the response to apoptosis. Some of these proteins (such as bcl-2 and bcl-XL) are anti-apoptotic, while others (such as Bad, Bax, or Bid) are pro-apoptotic. The sensitivity of cells to apoptotic stimuli depends on the balance of proand antiapoptotic bcl-2 proteins [156].

HSP70 affects the apoptosis death cascade at different levels. It can inhibit caspase activation by interfering with Apaf- 1 and prevent the recruitment of procaspase- 9 to the apoptosome [157, 158]. HSP70 also increases Bcl-2 expression and inhibits cytochrome $\mathrm{C}$ release; it also binds and sequesters AIF [159, 160]. Overexpression of HSP70 in lymphoid tumor cell lines appears to inhibit apoptosis by blocking caspase activation and activity [161]. The anti-apo-ptotic effects of HSP70 have been studied in brain tissue, where mice overexpressing HSP70 had decreased infarct sizes, improved neurological deficits, fewer apoptotic cells, and reduced DNA laddering after middle cerebral artery occlusion $[162,163]$.

As an anti-inflammatory molecule, HSP70 decreases the release of inflammatory mediators in different models of inflammation [164-166]. It has been suggested that HSP70 interacts with NF- $\kappa \mathrm{B}$ to exert this anti-inflammatory effect. $\mathrm{NF}-\kappa \mathrm{B}$ is a ubiquitous transcription factor that plays an 
essential role in inflammatory responses to a variety of signals, immune function, endothelial cell activation, and the control of cell growth [167-169]. NF- $\kappa \mathrm{B}$ is normally located in the cytoplasm in an inactive form by virtue of binding to a family of inhibitor of NF- $\kappa \mathrm{B}(\mathrm{I} \kappa \mathrm{B})$ proteins. Upon cell stimulation by a wide variety of stimuli, signal responsive IKK $\alpha$ and $-\beta$ (TNF-a-inducible IkB kinase complex also known as IKK-1 and IKK-2) are activated, which results in the phosphorylation of $\mathrm{I} \kappa \mathrm{B}$ and its proteasomal degradation. $\mathrm{I} \kappa \mathrm{B}$ degradation liberates $\mathrm{NF}-\kappa \mathrm{B}$, allowing it to translocate to the nucleus and induce gene expression. Induction of HSP72 in vitro (by heat shock or HSP72 overexpression) regulates the expression of inflammatory genes such as TNF- $\alpha$, IL1, IL-12, IL-10, and IL-18 [165, 166, 170-172]. Ran et al. [173] showed that HSP70 can, in fact, directly interact with IKK $-\gamma$ and prevent $\mathrm{I} \kappa \mathrm{B}$ phosphorylation. Chronic activation of IKK occurs in diabetic patients and it has been shown that the reduced IKK activity of the NF- $\kappa \mathrm{B}$ pathway prevents the development of insulin resistance in vitro and in vivo $[174,175]$. High-fat, high-carbohydrate meals cause a greater and more prolonged oxidative stress and NF- $\kappa \mathrm{B}$ activation in obese subjects [176]. Therefore, it can be concluded that IKK and NF- $\kappa \mathrm{B}$ activation are among the most important negative regulators in the development of type II diabetes that are opposed by HSPs.

Another mechanism for the anti-inflammatory effects of HSP72 involves inhibition of high-mobility group box 1 (HMGB1) release. HMGB1 is a pro-inflammatory nuclear protein that mediates responses to infection, injury, and inflammation [177]. It is secreted by activated macrophages in response to exogenous and endogenous inflammatory stimuli (such as endotoxin, TNF- $\alpha$, IL-1, IFN- $\gamma$, and hydrogen peroxide) and is released passively by necrotic and damaged cells [178]. Upon its release, HMGB1 binds to cell surface receptors including the receptors for AGEs, tolllike receptor 2 (TLR2), and TLR4. AGEs receptors are expressed on endothelial and smooth muscle cells, monocytes/ macrophages, neurons, and in several malignant and transformed cells [179]. Fiuza et al. [180] showed that HMGB1 stimulates human endothelial cells to increase the expression of intercellular and vascular adhesion molecules (ICAM-1 and VCAM-1), AGEs receptors as well as proinflammatory cytokine (TNF- $\alpha$ ) and chemokines (IL- 8 and monocyte chemotactic protein-1). This proinflammatory phenotype is mediated in part by early TNF- $\alpha$ secretion and involves the activation of stress mitogen activated protein kinase (MAPK) pathways and the transcription factor NF- $\kappa \mathrm{B}$ [180]. MAPKs and the $\mathrm{NF}-\kappa \mathrm{B} / \mathrm{I} \kappa \mathrm{B}$ pathway play important roles in inflammation because of the rapidity and extent of activation of transcription of NF- $\kappa \mathrm{B}$ [181]. High circulating levels of HMGB1 occur in type I and type II diabetic patients $[182,183]$. In an animal model, hyperglycemia induced by infusion of glucose also elevates serum levels of HMGB1 [184]. Other important actions of HSP in the inflammatory response include HSPs reduce LPS-induced HMGB1 release from macrophage cultures [185]; HSP72 negatively regulates oxidative stress-induced HMGB1 cytoplasmic translocation and release [186] and HSP72 overexpression inhibits HMGB1-induced cytokine (TNF- $\alpha$, IL-1 $\beta$ ) expression and release via inhibition of the MAPKs and NF- $\kappa$ B pathways [187].

\section{Summary}

The key roles of inflammation and oxidative stress in the pathogenesis and progression of diabetes are well accepted and their biomarkers are being increasingly used in the management and risk assessment of diabetic patients. There are multiple sources of ROS production in diabetes including those of mitochondrial and non-mitochondrial origins; increased production of ROS and a concomitant decline of antioxidant defense mechanisms leads to damage of cellu-lar organelles and enzymes and development of insulin resistance. Emerging evidence suggests that exercise activates the expression of cellular anti-oxidant systems and there is evidence to suggest that Nrf2 plays a critical role in this regard. Exercise produces a short-term pro-inflammatory response that is followed by a long-term anti-inflammatory effect. Regular exercise is associated with lower levels of CRP, IL6 and TNF- $\alpha$ and, simultaneously, with increases in antiinflammatory substances such as IL-4 and IL-10. The healthbeneficial effects of exercise-induced myokines and heat shock protein and their proposed mechanisms are gaining increased recognition.

\section{References}

[1] G. Vassort and B. Turan, "Protective role of antioxidants in diabetes-induced cardiac dysfunction," Cardiovascular Toxicology, vol. 10, no. 2, pp. 73-86, 2010.

[2] S. Ghosh, S. Golbidi, I. Werner, B. C. Verchere, and I. Laher, "Selecting exercise regimens and strains to modify obesity and diabetes in rodents: an overview," Clinical Science, vol. 119, no. 2, pp. 57-74, 2010.

[3] S. Zanuso, A. Jimenez, G. Pugliese, G. Corigliano, and S. Balducci, "Exercise for the management of type 2 diabetes: a review of the evidence," Acta Diabetologica, vol. 47, no. 1, pp. 15-22, 2010.

[4] S. Golbidi and I. Laher, "Molecular mechanisms in exerciseinduced cardioprotection," Cardiology Research and Practice, vol. 2011, Article ID 972807, 15 pages, 2011.

[5] S. Zanuso, S. Balducci, and A. Jimenez, "Physical activity, a key factor to quality of life in type 2 diabetic patients," Diabetes/Metabolism Research and Reviews, vol. 25, no. 1, pp. S24-S28, 2009.

[6] W. C. Duckworth, "Hyperglycemia and cardiovascular disease," Current Atherosclerosis Reports, vol. 3, no. 5, pp. 383$391,2001$.

[7] S. M. Grundy, I. J. Benjamin, G. L. Burke et al., "Diabetes and cardiovascular disease: a statement for healthcare professionals from the american heart association," Circulation, vol. 100, no. 10, pp. 1134-1146, 1999.

[8] N. Bashan, J. Kovsan, I. Kachko, H. Ovadia, and A. Rudich, "Positive and negative regulation of insulin signaling by reactive oxygen and nitrogen species," Physiological Reviews, vol. 89, no. 1, pp. 27-71, 2009.

[9] A. P. Rolo and C. M. Palmeira, "Diabetes and mitochondrial function: role of hyperglycemia and oxidative stress," Toxicology and Applied Pharmacology, vol. 212, no. 2, pp. 167-178, 2006. 
[10] M. Brownlee, "Biochemistry and molecular cell biology of diabetic complications," Nature, vol. 414, no. 6865 , pp. 813$820,2001$.

[11] M. Brownlee, "The pathobiology of diabetic complications: a unifying mechanism," Diabetes, vol. 54, no. 6, pp. 1615-1625, 2005.

[12] T. Nishikawa, D. Edelstein, X. L. Du et al., "Normalizing mitochondrial superoxide production blocks three pathways of hyperglycaemic damage," Nature, vol. 404, no. 6779, pp. 787-790, 2000.

[13] R. T. Iborra, I. C. D. Ribeiro, M. Q. T. S. Neves et al., "Aerobic exercise training improves the role of high-density lipoprotein antioxidant and reduces plasma lipid peroxidation in type 2 diabetes mellitus," Scandinavian Journal of Medicine and Science in Sports, vol. 18, no. 6, pp. 742-750, 2008.

[14] N. Kostić, Z. Čaparević, D. Marina et al., "Clinical evaluation of oxidative stress in patients with diabetes mellitus type IIimpact of acute exercise," Vojnosanitetski Pregled, vol. 66, no. 6, pp. 459-464, 2009.

[15] C. K. Roberts, D. Won, S. Pruthi, S. S. Lin, and R. J. Barnard, "Effect of a diet and exercise intervention on oxidative stress, inflammation and monocyte adhesion in diabetic men," Diabetes Research and Clinical Practice, vol. 73, no. 3, pp. 249259, 2006.

[16] H. Nojima, H. Watanabe, K. Yamane et al., "Effect of aerobic exercise training on oxidative stress in patients with type 2 diabetes mellitus," Metabolism, vol. 57, no. 2, pp. 170-176, 2008.

[17] T. P. Wycherley, G. D. Brinkworth, M. Noakes, J. D. Buckley, and P. M. Clifton, "Effect of caloric restriction with and without exercise training on oxidative stress and endothelial function in obese subjects with type 2 diabetes," Diabetes, Obesity and Metabolism, vol. 10, no. 11, pp. 1062-1073, 2008.

[18] L. A. Gordon, E. Y. Morrison, D. A. McGrowder et al., "Effect of exercise therapy on lipid profile and oxidative stress indicators in patients with type 2 diabetes," BMC Complementary and Alternative Medicine, vol. 8, article 21, 2008.

[19] S. C. Chen, K. C. Ueng, S. H. Lee, K. T. Sun, and M. C. Lee, "Effect of T'ai Chi exercise on biochemical profiles and oxidative stress indicators in obese patients with type 2 diabetes," Journal of Alternative and Complementary Medicine, vol. 16, no. 11, pp. 1153-1159, 2010.

[20] L. Villa-Caballero, A. A. Nava-Ocampo, A. C. Frati-Munari et al., "Hemodynamic and oxidative stress profile after exercise in type 2 diabetes," Diabetes Research and Clinical Practice, vol. 75, no. 3, pp. 285-291, 2007.

[21] S. F. E. Praet, R. A. M. Jonkers, G. Schep et al., "Longstanding, insulin-treated type 2 diabetes patients with complications respond well to short-term resistance and interval exercise training," European Journal of Endocrinology, vol. 158, no. 2, pp. 163-172, 2008.

[22] S. Balducci, S. Zanuso, A. Nicolucci et al., "Anti-inflammatory effect of exercise training in subjects with type 2 diabetes and the metabolic syndrome is dependent on exercise modalities and independent of weight loss," Nutrition, Metabolism and Cardiovascular Diseases, vol. 20, no. 8, pp. 608-617, 2010.

[23] C. Herder, M. Peltonen, W. Koenig et al., "Anti-inflammatory effect of lifestyle changes in the Finnish Diabetes Prevention Study," Diabetologia, vol. 52, no. 3, pp. 433-442, 2009.

[24] P. Araiza, H. Hewes, C. Gashetewa, C. A. Vella, and M. R. Burge, "Efficacy of a pedometer-based physical activity program on parameters of diabetes control in type 2 diabetes mellitus," Metabolism, vol. 55, no. 10, pp. 1382-1387, 2006.
[25] N. P. E. Kadoglou, I. S. Vrabas, N. Sailer et al., "Exercise ameliorates serum MMP-9 and TIMP-2 levels in patients with type 2 diabetes," Diabetes and Metabolism, vol. 36, no. 2, pp. 144-151, 2010.

[26] A. Oberbach, S. Lehmann, K. Kirsch et al., "Long-term exercise training decreases interleukin-6 (IL-6) serum levels in subjects with impaired glucose tolerance: effect of the -174G/ C variant in IL-6 gene," European Journal of Endocrinology, vol. 159, no. 2, pp. 129-136, 2008.

[27] L. M. Yung, F. P. Leung, X. Yao, Z. Y. Chen, and Y. Huang, "Reactive oxygen species in vascular wall," Cardiovascular and Hematological Disorders, vol. 6, no. 1, pp. 1-19, 2006.

[28] L. M. Henderson and J. B. Chappell, "NADPH oxidase of neutrophils," Biochimica et Biophysica Acta, vol. 1273, no. 2, pp. 87-107, 1996.

[29] B. Lassègue and R. E. Clempus, "Vascular NAD(P)H oxidases: specific features, expression, and regulation," American Journal of Physiology, vol. 285, no. 2, pp. R277-R297, 2003.

[30] L. Quagliaro, L. Piconi, R. Assaloni, L. Martinelli, E. Motz, and A. Ceriello, "Intermittent high glucose enhances apoptosis related to oxidative stress in human umbilical vein endothelial cells: the role of protein kinase $\mathrm{C}$ and $\mathrm{NAD}(\mathrm{P}) \mathrm{H}$-oxidase activation," Diabetes, vol. 52, no. 11, pp. 2795-2804, 2003.

[31] H. Hua, S. Munk, H. Goldberg, I. G. Fantus, and C. I. Whiteside, "High glucose-suppressed endothelin-1 $\mathrm{Ca}^{2+}$ signaling via NADPH oxidase and diacylglycerol-sensitive protein kinase C isozymes in mesangial cells," Journal of Biological Chemistry, vol. 278, no. 36, pp. 33951-33962, 2003.

[32] T. Seno, N. Inoue, D. Gao et al., "Involvement of NADH/ NADPH oxidase in human platelet ROS production," Thrombosis Research, vol. 103, no. 5, pp. 399-409, 2001.

[33] A. Perner, L. Andresen, G. Pedersen, and J. Rask-Madsen, "Superoxide production and expression of $\mathrm{NAD}(\mathrm{P}) \mathrm{H}$ oxidases by transformed and primary human colonic epithelial cells," Gut, vol. 52, no. 2, pp. 231-236, 2003.

[34] C. Dupuy, A. Virion, R. Ohayon, J. Kaniewski, D. Deme, and J. Pommier, "Mechanism of hydrogen peroxide formation catalyzed by NADPH oxidase in thyroid plasma membrane," Journal of Biological Chemistry, vol. 266, no. 6, pp. 37393743, 1991.

[35] H. Cai, K. K. Griendling, and D. G. Harrison, "The vascular $\mathrm{NAD}(\mathrm{P}) \mathrm{H}$ oxidases as therapeutic targets in cardiovascular diseases," Trends in Pharmacological Sciences, vol. 24, no. 9, pp. 471-478, 2003.

[36] R. M. Touyz, C. Deschepper, J. B. Park et al., "Inhibition of mitogen-activated protein/extracellular signal-regulated kinase improves endothelial function and attenuates Ang IIinduced contractility of mesenteric resistance arteries from spontaneously hypertensive rats," Journal of Hypertension, vol. 20, no. 6, pp. 1127-1134, 2002.

[37] J. A. Holland, J. W. Meyer, M. M. Chang, R. W. O’Donnell, D. K. Johnson, and L. M. Ziegler, "Thrombin stimulated reactive oxygen species production in cultured human endothelial cells," Endothelium, vol. 6, no. 2, pp. 113-121, 1998.

[38] T. Marumo, V. B. Schini-Kerth, B. Fisslthaler, and R. Busse, "Platelet-derived growth factor-stimulated superoxide anion production modulates activation of transcription factor NF$\kappa \mathrm{B}$ and expression of monocyte chemoattractant protein 1 in human aortic smooth muscle cells," Circulation, vol. 96, no. 7, pp. 2361-2367, 1997.

[39] G. W. De Keulenaer, R. W. Alexander, M. Ushio-Fukai, N. Ishizaka, and K. K. Griendling, "Tumour necrosis factor $\alpha$ activates a 22 phox-based NADH oxidase in vascular smooth 
muscle," Biochemical Journal, vol. 329, no. 3, pp. 653-657, 1998.

[40] U. Hink, H. Li, H. Mollnau et al., "Mechanisms underlying endothelial dysfunction in diabetes mellitus," Circulation Research, vol. 88, no. 2, pp. E14-22, 2001.

[41] T. J. Guzik, S. Mussa, D. Gastaldi et al., "Mechanisms of increased vascular superoxide production in human diabetes mellitus: role of $\mathrm{NAD}(\mathrm{P}) \mathrm{H}$ oxidase and endothelial nitric oxide synthase," Circulation, vol. 105, no. 14, pp. 1656-1662, 2002.

[42] Z. Fatehi-Hassanabad, C. B. Chan, and B. L. Furman, "Reactive oxygen species and endothelial function in diabetes," European Journal of Pharmacology, vol. 636, no. 1-3, pp. 817, 2010.

[43] A. Paler-Martinez, P. C. Panus, P. H. Chumley, U. Ryan, M. M. Hardy, and B. A. Freeman, "Endogenous xanthine oxidase does not significantly contribute to vascular endothelial production of reactive oxygen species," Archives of Biochemistry and Biophysics, vol. 311, no. 1, pp. 79-85, 1994.

[44] G. Bruder, E. D. Jarasch, and H. W. Heid, "High concentrations of antibodies to xanthine oxidase in human and animal sera. Molecular characterization," Journal of Clinical Investigation, vol. 74, no. 3, pp. 783-794, 1984.

[45] R. S. Berman and W. Martin, "Arterial endothelial barrier dysfunction: actions of homocysteine and the hypoxanthinexanthine oxidase free radical generating system," British Journal of Pharmacology, vol. 108, no. 4, pp. 920-926, 1993.

[46] A. Salas, J. Panés, J. I. Elizalde, D. N. Granger, and J. M. Piqué, "Reperfusion-induced oxidative stress in diabetes: cellular and enzymatic sources," Journal of Leukocyte Biology, vol. 66, no. 1, pp. 59-66, 1999.

[47] M. C. Desco, M. Asensi, R. Márquez et al., "Xanthine oxidase is involved in free radical production in type 1 diabetes: protection by allopurinol," Diabetes, vol. 51, no. 4, pp. 11181124, 2002.

[48] R. Butler, A. D. Morris, J. J. F. Belch, A. Hill, and A. D. Struthers, "Allopurinol normalizes endothelial dysfunction in type 2 diabetics with mild hypertension," Hypertension, vol. 35, no. 3, pp. 746-751, 2000.

[49] H. Kuhn and B. J. Thiele, "The diversity of the lipoxygenase family. Many sequence data but little information on biological significance," FEBS Letters, vol. 449, no. 1, pp. 7-11, 1999.

[50] R. Natarajan and J. L. Nadler, "Lipoxygenases and lipid signaling in vascular cells in diabetes," Frontiers in Bioscience, vol. 8, pp. s783-s795, 2003.

[51] P. Dandona and A. Aljada, "A rational approach to pathogenesis and treatment of type 2 diabetes mellitus, insulin resistance, inflammation, and atherosclerosis," American Journal of Cardiology, vol. 90, no. 5, pp. 27G-33G, 2002.

[52] B. Tesfamariam, M. L. Brown, D. Deykin, and R. A. Cohen, "Elevated glucose promotes generation of endothelium-derived vasoconstrictor prostanoids in rabbit aorta," Journal of Clinical Investigation, vol. 85, no. 3, pp. 929-932, 1990.

[53] F. Cipollone, A. Iezzi, M. Fazia et al., "The receptor RAGE as a progression factor amplifying arachidonate-dependent inflammatory and proteolytic response in human atherosclerotic plaques: role of glycemic control," Circulation, vol. 108, no. 9, pp. 1070-1077, 2003.

[54] N. Shanmugam, I. T. G. Gonzalo, and R. Natarajan, "Molecular mechanisms of high glucose-induced cyclooxygenase-2 expression in monocytes," Diabetes, vol. 53, no. 3, pp. 795 802, 2004.

[55] S. Kiritoshi, T. Nishikawa, K. Sonoda et al., "Reactive oxygen species from mitochondria induce cyclooxygenase-2 gene expression in human mesangial cells: potential role in diabetic nephropathy," Diabetes, vol. 52, no. 10, pp. 2570-2577, 2003.

[56] A. A. Caro and A. I. Cederbaum, "Oxidative stress, toxicology, and pharmacology of CYP2E1," Annual Review of Pharmacology and Toxicology, vol. 44, pp. 27-42, 2004.

[57] P. J. Loida and S. G. Sligar, "Molecular recognition in cytochrome P-450: mechanism for the control of uncoupling reactions," Biochemistry, vol. 32, no. 43, pp. 11530-11538, 1993.

[58] V. Haufroid, D. Ligocka, M. Buysschaert, Y. Horsmans, and D. Lison, "Cytochrome P4502E1 (CYP2E1) expression in peripheral blood lymphocytes: evaluation in hepatitis $\mathrm{C}$ and diabetes," European Journal of Clinical Pharmacology, vol. 59, no. 1, pp. 29-33, 2003.

[59] Z. Wang, S. D. Hall, J. F. Maya, L. Li, A. Asghar, and J. C. Gorski, "Diabetes mellitus increases the in vivo activity of cytochrome P450 2E1 in humans," British Journal of Clinical Pharmacology, vol. 55, no. 1, pp. 77-85, 2003.

[60] I. A. Leclercq, J. Field, A. Enriquez, G. C. Farrell, and G. R. Robertson, "Constitutive and inducible expression of hepatic CYP2E1 in leptin-deficient ob/ob mice," Biochemical and Biophysical Research Communications, vol. 268, no. 2, pp. 337-344, 2000.

[61] L. V. Favreau, D. M. Malchoff, J. E. Mole, and J. B. Schenkman, "Responses to insulin by two forms of rat hepatic microsomal cytochrome P-450 that undergo major (RLM6) and minor (RLM5b) elevations in diabetes," Journal of Biological Chemistry, vol. 262, no. 29, pp. 14319-14326, 1987.

[62] A. Enriquez, I. Leclercq, G. C. Farrell, and G. Robertson, "Altered expression of hepatic CYP2E1 and CYP4A in obese, diabetic ob/ob mice, and fa/fa Zucker rats," Biochemical and Biophysical Research Communications, vol. 255, no. 2, pp. 300-306, 1999.

[63] S. Lee, Y. Park, M. Y. Zuidema, M. Hannink, and C. Zhang, "Effects of interventions on oxidative stress and inflammation of cardiovascular diseases," World Journal of Cardiology, vol. 3, no. 1, pp. 18-24, 2011.

[64] S. Golbidi and I. Laher, "Antioxidant therapy in human endocrine disorders," Medical Science Monitor, vol. 16, no. 1, pp. RA9-RA24, 2010.

[65] A. G. Cox, C. C. Winterbourn, and M. B. Hampton, "Mitochondrial peroxiredoxin involvement in antioxidant defence and redox signalling," Biochemical Journal, vol. 425, no. 2, pp. 313-325, 2010.

[66] T. S. Chang, C. S. Cho, S. Park, S. Yu, W. K. Sang, and G. R. Sue, "Peroxiredoxin III, a mitochondrion-specific peroxidase, regulates apoptotic signaling by mitochondria," Journal of Biological Chemistry, vol. 279, no. 40, pp. 4197541984, 2004.

[67] S. G. Rhee, S. W. Kang, T. S. Chang, W. Jeong, and K. Kim, "Peroxiredoxin, a novel family of peroxidases," IUBMB Life, vol. 52, no. 1-2, pp. 35-41, 2001.

[68] E. J. Calabrese and L. A. Baldwin, "Hormesis: a generalizable and unifying hypothesis," Critical Reviews in Toxicology, vol. 31, no. 4-5, pp. 353-424, 2001.

[69] J. Karolkiewicz, L. Szczêsniak, E. Deskur-Smielecka, A. Nowak, R. Stemplewski, and R. Szeklicki, "Oxidative stress and antioxidant defense system in healthy, elderly men: relationship to physical activity," Aging Male, vol. 6, no. 2, pp. 100-105, 2003.

[70] N. Inoue, S. Ramasamy, T. Fukai, R. M. Nerem, and D. G. Harrison, "Shear stress modulates expression of $\mathrm{Cu} / \mathrm{Zn}$ 
superoxide dismutase in human aortic endothelial cells," Circulation Research, vol. 79, no. 1, pp. 32-37, 1996.

[71] J. Hollander, R. Fiebig, M. Gore et al., "Superoxide dismutase gene expression in skeletal muscle: fiber-specific adaptation to endurance training," American Journal of Physiology, vol. 277, no. 3, pp. R856-R862, 1999.

[72] F. Moien-Afshari, S. Ghosh, M. Khazaei, T. J. Kieffer, R. W. Brownsey, and I. Laher, "Exercise restores endothelial function independently of weight loss or hyperglycaemic status in db/db mice," Diabetologia, vol. 51, no. 7, pp. 1327-1337, 2008.

[73] X. Cheng, R. C. M. Siow, and G. E. Mann, "Impaired redox signaling and antioxidant gene expression in endothelial cells in diabetes: a role for mitochondria and the nuclear factor-E2-related factor 2-Kelch-like ECH-associated protein 1 defense pathway," Antioxidants and Redox Signaling, vol. 14, no. 3, pp. 469-487, 2011.

[74] W. Bao, F. Song, X. Li et al., "Plasma heme oxygenase-1 concentration is elevated in individuals with type 2 diabetes mellitus," PLoS ONE, vol. 5, no. 8, Article ID e12371, 2010.

[75] E. Babusikova, M. Jesenak, P. Durdik, D. Dobrota, and P. Banovcin, "Exhaled carbon monoxide as a new marker of respiratory diseases in children," Journal of Physiology and Pharmacology, vol. 59, no. 6, pp. 9-17, 2008.

[76] G. F. Vile and R. M. Tyrrell, "Oxidative stress resulting from ultraviolet A irradiation of human skin fibroblasts leads to a heme oxygenase-dependent increase in ferritin," Journal of Biological Chemistry, vol. 268, no. 20, pp. 14678-14681, 1993.

[77] S. Bélanger, J. C. Lavoie, and P. Chessex, "Influence of bilirubin on the antioxidant capacity of plasma in newborn infants," Biology of the Neonate, vol. 71, no. 4, pp. 233-238, 1997.

[78] S. W. Ryter, J. Alam, and A. M. K. Choi, "Heme oxygenase$1 /$ carbon monoxide: from basic science to therapeutic applications," Physiological Reviews, vol. 86, no. 2, pp. 583-650, 2006.

[79] A. M. Niess, F. Passek, I. Lorenz et al., "Expression of the antioxidant stress protein heme oxygenase-1 (HO-1) in human leukocytes: acute and adaptational responses to endurance exercise," Free Radical Biology and Medicine, vol. 26, no. 1-2, pp. 184-192, 1999.

[80] M. Asghar, L. George, and M. F. Lokhandwala, "Exercise decreases oxidative stress and inflammation and restores renal dopamine D1 receptor function in old rats," American Journal of Physiology, vol. 293, no. 3, pp. F914-F919, 2007.

[81] H. A. Demirel, S. K. Powers, M. A. Zergeroglu et al., "Shortterm exercise improves myocardial tolerance to in vivo ischemia-reperfusion in the rat," Journal of Applied Physiology, vol. 91, no. 5, pp. 2205-2212, 2001.

[82] N. Yamashita, S. Hoshida, K. Otsu, M. Asahi, T. Kuzuya, and M. Hori, "Exercise provides direct biphasic cardioprotection via manganese superoxide dismutase activation," Journal of Experimental Medicine, vol. 189, no. 11, pp. 1699-1706, 1999.

[83] D. A. Brown, K. N. Jew, G. C. Sparagna, T. I. Musch, and R. L. Moore, "Exercise training preserves coronary flow and reduces infarct size after ischemia-reperfusion in rat heart," Journal of Applied Physiology, vol. 95, no. 6, pp. 2510-2518, 2003.

[84] C. P. Reddy-Avula and G. Fernandes, "Modulation of antioxidant enzymes and lipid peroxidation in salivary gland and other tissues in mice by moderate treadmill exercise," Aging, vol. 11, no. 4, pp. 246-252, 1999.

[85] J. Karanth and K. Jeevaratnam, "Oxidative stress and antioxidant status in rat blood, liver and muscle: effect of dietary lipid, carnitine and exercise," International Journal for Vitamin and Nutrition Research, vol. 75, no. 5, pp. 333-339, 2005.

[86] P. Silacci, A. Desgeorges, L. Mazzolai, C. Chambaz, and D. Hayoz, "Flow pulsatility is a critical determinant of oxidative stress in endothelial cells," Hypertension, vol. 38, no. 5, pp. 1162-1166, 2001.

[87] J. Y. Park, R. E. Ferrel, J. J. Park et al., "NADPH oxidase p22phox gene variants are associated with systemic oxidative stress biomarker responses to exercise training," Journal of Applied Physiology, vol. 99, no. 5, pp. 1905-1911, 2005.

[88] F. P. Leung, L. M. Yung, I. Laher, X. Yao, Z. Y. Chen, and Y. Huang, "Exercise, vascular wall and cardiovascular diseases: an update (part 1)," Sports Medicine, vol. 38, no. 12, pp. 10091024, 2008.

[89] A. Ray, M. V. Huisman, J. T. Tamsma et al., "The role of inflammation on atherosclerosis, intermediate and clinical cardiovascular endpoints in type 2 diabetes mellitus," European Journal of Internal Medicine, vol. 20, no. 3, pp. 253-260, 2009.

[90] N. Sallam, A. Fisher, S. Golbidi, and I. Laher, "Weight and inflammation are the major determinants of vascular dysfunction in the aortae of db/db mice," Naunyn-Schmiedeberg's Archives of Pharmacology, vol. 383, no. 5, pp. 483-492, 2011.

[91] S. B. Thomsen, C. N. Rathcke, B. Zerahn, and H. Vestergaard, "Increased levels of the calcification marker Matrix Gla Protein and the inflammatory markers YKL-40 and CRP in patients with type 2 diabetes and ischemic heart disease," Cardiovascular Diabetology, vol. 9, article 86, 2010.

[92] S. Balducci, S. Zanuso, A. Nicolucci et al., "Anti-inflammatory effect of exercise training in subjects with type 2 diabetes and the metabolic syndrome is dependent on exercise modalities and independent of weight loss," Nutrition, Metabolism and Cardiovascular Diseases, vol. 20, no. 8, pp. 608$617,2010$.

[93] T. A. Pearson, G. A. Mensah, R. W. Alexander et al., "Markers of inflammation and cardiovascular disease: application to clinical and public health practice: a statement for healthcare professionals from the centers for disease control and prevention and the American Heart Association," Circulation, vol. 107, no. 3, pp. 499-511, 2003.

[94] A. H. Sprague and R. A. Khalil, "Inflammatory cytokines in vascular dysfunction and vascular disease," Biochemical Pharmacology, vol. 78, no. 6, pp. 539-552, 2009.

[95] S. Tiwari, Y. Zhang, J. Heller, D. R. Abernethy, and N. M. Soldatov, "Artherosclerosis-related molecular alteration of the human Ca V1.2 calcium channel $\alpha 1 \mathrm{C}$ subunit," Proceedings of the National Academy of Sciences of the United States of America, vol. 103, no. 45, pp. 17024-17029, 2006.

[96] J. Hiroki, H. Shimokawa, M. Higashi et al., "Inflammatory stimuli upregulate Rho-kinase in human coronary vascular smooth muscle cells," Journal of Molecular and Cellular Cardiology, vol. 37, no. 2, pp. 537-546, 2004.

[97] C. Zhang, Y. Park, A. Picchi, and B. J. Potter, "Maturationinduces endothelial dysfunction via vascular inflammation in diabetic mice," Basic Research in Cardiology, vol. 103, no. 5, pp. 407-416, 2008.

[98] J. A. Mitchell, S. Larkin, and T. J. Williams, "Cyclooxygenase2: regulation and relevance in inflammation," Biochemical Pharmacology, vol. 50, no. 10, pp. 1535-1542, 1995.

[99] N. Erdei, Z. Bagi, I. Édes, G. Kaley, and A. Koller, " $\mathrm{H}_{2} \mathrm{O}_{2}$ increases production of constrictor prostaglandins in smooth muscle leading to enhanced arteriolar tone in Type 2 diabetic mice," American Journal of Physiology, vol. 292, no. 1, pp. H649-H656, 2007. 
[100] T. Matsumoto, M. Kakami, E. Noguchi, T. Kobayashi, and K. Kamata, "Imbalance between endothelium-derived relaxing and contracting factors in mesenteric arteries from aged OLETF rats, a model of Type 2 diabetes," American Journal of Physiology, vol. 293, no. 3, pp. H1480-H1490, 2007.

[101] E. H. C. Tang, F. P. Leung, Y. Huang et al., "Calcium and reactive oxygen species increase in endothelial cells in response to releasers of endothelium-derived contracting factor," British Journal of Pharmacology, vol. 151, no. 1, pp. 1523, 2007.

[102] N. Kanie and K. Kamata, "Contractile responses in spontaneously diabetic mice: I. Involvement of superoxide anion in enhanced contractile response of aorta to norepinephrine in C57BL/KsJ(db/db) mice," General Pharmacology, vol. 35, no. 6, pp. 311-318, 2000.

[103] E. B. Okon, T. Szado, I. Laher, B. McManus, and C. Van Breemena, "Augmented contractile response of vascular smooth muscle in a diabetic mouse model," Journal of Vascular Research, vol. 40, no. 6, pp. 520-530, 2003.

[104] Z. Guo, W. Su, S. Allen et al., "COX-2 Up-regulation and vascular smooth muscle contractile hyperreactivity in spontaneous diabetic db/db mice," Cardiovascular Research, vol. 67, no. 4, pp. 723-735, 2005.

[105] M. Pannirselvam, W. B. Wiehler, T. Anderson, and C. R. Triggle, "Enhanced vascular reactivity of small mesenteric arteries from diabetic mice is associated with enhanced oxidative stress and cyclooxygenase products," British Journal of Pharmacology, vol. 144, no. 7, pp. 953-960, 2005.

[106] Y. Shi and P. M. Vanhoutte, "Oxidative stress and COX cause hyper-responsiveness in vascular smooth muscle of the femoral artery from diabetic rats," British Journal of Pharmacology, vol. 154, no. 3, pp. 639-651, 2008.

[107] A. S. Kelly, A. M. Thelen, D. R. Kaiser, J. M. Gonzalez-Campoy, and A. J. Bank, "Rosiglitazone improves endothelial function and inflammation but not asymmetric dimethylarginine or oxidative stress inpatients with type 2 diabetes mellitus," Vascular Medicine, vol. 12, no. 4, pp. 311-318, 2007.

[108] C. Kasapis and P. D. Thompson, "The effects of physical activity on serum C-reactive protein and inflammatory markers: a systematic review," Journal of the American College of Cardiology, vol. 45, no. 10, pp. 1563-1569, 2005.

[109] E. P. Plaisance and P. W. Grandjean, "Physical activity and high-sensitivity C-reactive protein," Sports Medicine, vol. 36, no. 5, pp. 443-458, 2006.

[110] K. E. Fallon, S. K. Fallon, and T. Boston, "The acute phase response and exercise: court and field sports," British Journal of Sports Medicine, vol. 35, no. 3, pp. 170-173, 2001.

[111] M. L. Kohut, D. A. McCann, D. W. Russell et al., "Aerobic exercise, but not flexibility/resistance exercise, reduces serum IL-18, CRP, and IL-6 independent of $\beta$-blockers, BMI, and psychosocial factors in older adults," Brain, Behavior, and Immunity, vol. 20, no. 3, pp. 201-209, 2006.

[112] B. K. Pedersen, "The diseasome of physical inactivity-and the role of myokines in muscle-fat cross talk," Journal of Physiology, vol. 587, no. 23, pp. 5559-5568, 2009.

[113] C. Brandt and B. K. Pedersen, "The role of exercise-induced myokines in muscle homeostasis and the defense against chronic diseases," Journal of Biomedicine and Biotechnology, vol. 2010, Article ID 520258, 6 pages, 2010.

[114] A. M. W. Petersen and B. K. Pedersen, "The anti-inflammatory effect of exercise," Journal of Applied Physiology, vol. 98, no. 4, pp. 1154-1162, 2005.
[115] M. A. Febbraio and B. K. Pedersen, "Contraction-induced myokine production and release: is skeletal muscle an endocrine organ?" Exercise and Sport Sciences Reviews, vol. 33, no. 3, pp. 114-119, 2005.

[116] B. K. Pedersen and C. P. Fischer, "Beneficial health effects of exercise-the role of IL-6 as a myokine," Trends in Pharmacological Sciences, vol. 28, no. 4, pp. 152-156, 2007.

[117] D. C. Nieman, J. M. Davis, D. A. Henson et al., "Carbohydrate ingestion influences skeletal muscle cytokine mRNA and plasma cytokine levels after a 3-h run," Journal of Applied Physiology, vol. 94, no. 5, pp. 1917-1925, 2003.

[118] C. Keller, A. Steensberg, H. Pilegaard et al., "Transcriptional activation of the IL-6 gene in human contracting skeletal muscle: influence of muscle glycogen content," FASEB Journal, vol. 15, no. 14, pp. 2748-2750, 2001.

[119] B. K. Pedersen and M. A. Febbraio, "Point: interleukin-6 does have a beneficial role in insulin sensitivity and glucose homeostasis," Journal of Applied Physiology, vol. 102, no. 2, pp. 804806, 2007.

[120] A. Festa, R. D’Agostino Jr., G. Howard, L. Mykkänen, R. P. Tracy, and S. M. Haffner, "Chronic subclinical inflammation as part of the insulin resistance syndrome: the insulin resistance atherosclerosis study (IRAS)," Circulation, vol. 102, no. 1, pp. 42-47, 2000.

[121] R. Starkie, S. R. Ostrowski, S. Jauffred, M. Febbraio, and B. K. Pedersen, "Exercise and IL-6 infusion inhibit endotoxininduced TNF- $\alpha$ production in humans," FASEB Journal, vol. 17, no. 8, pp. 884-886, 2003.

[122] C. Keller, P. Keller, M. Giralt, J. Hidalgo, and B. K. Pedersen, "Exercise normalises overexpression of TNF- $\alpha$ in knockout mice," Biochemical and Biophysical Research Communications, vol. 321, no. 1, pp. 179-182, 2004.

[123] T. Van Der Poll, S. M. Coyle, K. Barbosa, C. C. Braxton, and S. F. Lowry, "Epinephrine inhibits tumor necrosis factor- $\alpha$ and potentiates interleukin 10 production during human endotoxemia," Journal of Clinical Investigation, vol. 97, no. 3, pp. 713-719, 1996.

[124] E. W. Petersen, A. L. Carey, M. Sacchetti et al., "Acute IL6 treatment increases fatty acid turnover in elderly humans in vivo and in tissue culture in vitro," American Journal of Physiology, vol. 288, no. 1, pp. E155-E162, 2005.

[125] V. Wallenius, K. Wallenius, B. Ahrén et al., "Interleukin-6-deficient mice develop mature-onset obesity," Nature Medicine, vol. 8, no. 1, pp. 75-79, 2002.

[126] G. Van Hall, A. Steensberg, M. Sacchetti et al., "Interleukin6 stimulates lipolysis and fat oxidation in humans," Journal of Clinical Endocrinology and Metabolism, vol. 88, no. 7, pp. 3005-3010, 2003.

[127] E. Hopps, B. Canino, and G. Caimi, "Effects of exercise on inflammation markers in type 2 diabetic subjects," Acta Diabetol, vol. 48, no. 3, pp. 183-189, 2011.

[128] M. S. Marber, R. Mestril, S. H. Chi, M. R. Sayen, D. M. Yellon, and W. H. Dillmann, "Overexpression of the rat inducible $70-\mathrm{kD}$ heat stress protein in a transgenic mouse increases the resistance of the heart to ischemic injury," Journal of Clinical Investigation, vol. 95, no. 4, pp. 1446-1456, 1995.

[129] S. D. Guttman, C. V. C. Glover, C. D. Allis, and M. A. Gorovsky, "Heat shock, deciliation and release from anoxia induce the synthesis of the same set of polypeptides in starved T. pyriformis," Cell, vol. 22, no. 1, pp. 299-307, 1980.

[130] G. Weitzel, U. Pilatus, and L. Rensing, "Similar dose response of heat shock protein synthesis and intracellular $\mathrm{pH}$ change in yeast," Experimental Cell Research, vol. 159, no. 1, pp. 252256, 1985. 
[131] C. Adrie, C. Richter, M. Bachelet et al., "Contrasting effects of NO and peroxynitrites on HSP70 expression and apoptosis in human monocytes," American Journal of Physiology, vol. 279, no. 2, pp. C452-C460, 2000.

[132] H. L. Chiang, S. R. Terlecky, C. P. Plant, and J. F. Dice, "A role for a 70-kilodaton heat shock protein in lysosomal degradation of intracellular proteins," Science, vol. 246, no. 4928, pp. 382-385, 1989.

[133] W. J. Welch, J. I. Garrels, G. P. Thomas, J. J. Lin, and J. R. Feramisco, "Biochemical characterization of the mammalian stress proteins and identification of two stress proteins as glucose- and $\mathrm{Ca}^{2+}$-ionophore-regulated proteins," Journal of Biological Chemistry, vol. 258, no. 11, pp. 7102-7111, 1983.

[134] J. J. Sciandra and J. R. Subjeck, "The effects of glucose on protein synthesis and thermosensitivity in Chinese hamster ovary cells," Journal of Biological Chemistry, vol. 258, no. 20, pp. 12091-12093, 1983.

[135] M. Locke, "The cellular stress response to exercise: role of stress proteins," Exercise and Sport Sciences Reviews, vol. 25, pp. 105-136, 1997.

[136] J. L. Kilgore, T. I. Musch, and C. R. Ross, "Physical activity, muscle, and the HSP70 response," Canadian Journal of Applied Physiology, vol. 23, no. 3, pp. 245-260, 1998.

[137] K. C. Kregel, "Invited review: heat shock proteins: modifying factors in physiological stress responses and acquired thermotolerance," Journal of Applied Physiology, vol. 92, no. 5, pp. 2177-2186, 2002.

[138] W. J. Welch, "Mammalian stress response: cell physiology, structure/function of stress proteins, and implications for medicine and disease," Physiological Reviews, vol. 72, no. 4, pp. 1063-1081, 1992.

[139] J. P. Morton, A. C. Kayani, A. McArdle, and B. Drust, "The exercise-induced stress response of skeletal muscle, with specific emphasis on humans," Sports Medicine, vol. 39, no. 8, pp. 643-662, 2009.

[140] P. C. Geiger and A. A. Gupte, "Heat shock proteins are important mediators of skeletal muscle insulin sensitivity," Exercise and Sport Sciences Reviews, vol. 39, no. 1, pp. 34-42, 2011.

[141] I. Kurucz, A. Morva, A. Vaag et al., "Decreased expression of heat shock protein 72 in skeletal muscle of patients with type 2 diabetes correlates with insulin resistance," Diabetes, vol. 51, no. 4, pp. 1102-1109, 2002.

[142] M. Atalay, N. Oksala, J. Lappalainen, D. E. Laaksonen, C. K. Sen, and S. Roy, "Heat shock proteins in diabetes and wound healing," Current Protein and Peptide Science, vol. 10, no. 1, pp. 85-95, 2009.

[143] G. N. Bijur and R. S. Jope, "Opposing actions of phosphatidylinositol 3-kinase and glycogen synthase kinase-3 $\beta$ in the regulation of HSF-1 activity," Journal of Neurochemistry, vol. 75, no. 6, pp. 2401-2408, 2000.

[144] J. Chung, A. K. Nguyen, D. C. Henstridge et al., "HSP72 protects against obesity-induced insulin resistance," Proceedings of the National Academy of Sciences of the United States of America, vol. 105, no. 5, pp. 1739-1744, 2008.

[145] L. Vigh, I. Horváth, B. Maresca, and J. L. Harwood, "Can the stress protein response be controlled by 'membrane-lipid therapy'?” Trends in Biochemical Sciences, vol. 32, no. 8, pp. 357-363, 2007.

[146] S. P. Patel and S. S. Katyare, "Insulin status-dependent alterations in lipid/phospholipid composition of rat kidney microsomes and mitochondria," Lipids, vol. 41, no. 9, pp. 819-825, 2006.

[147] R. C. Walsh, I. Koukoulas, A. Garnham, P. L. Moseley, M. Hargreaves, and M. A. Febbraio, "Exercise increases serum
Hsp72 in humans," Cell Stress and Chaperones, vol. 6, no. 4, pp. 386-393, 2001.

[148] C. P. Fischer, N. J. Hiscock, S. Basu et al., "Vitamin E isoformspecific inhibition of the exercise-induced heat shock protein 72 expression in humans," Journal of Applied Physiology, vol. 100, no. 5, pp. 1679-1687, 2006.

[149] M. Khassaf, A. McArdle, C. Esanu et al., "Effect of vitamin $\mathrm{C}$ supplements on antioxidant defence and stress proteins in human lymphocytes and skeletal muscle," Journal of Physiology, vol. 549, no. 2, pp. 645-652, 2003.

[150] M. J. Jackson, M. Khassaf, A. Vasilaki, F. McArdle, and A. McArdle, "Vitamin E and the oxidative stress of exercise," Annals of the New York Academy of Sciences, vol. 1031, pp. 158-168, 2004.

[151] H. S. Thompson, S. P. Scordilis, P. M. Clarkson, and W. A. Lohrer, "A single bout of eccentric exercise increases HSP27 and HSC/HSP70 in human skeletal muscle," Acta Physiologica Scandinavica, vol. 171, no. 2, pp. 187-193, 2001.

[152] L. Féasson, D. Stockholm, D. Freyssenet et al., "Molecular adaptations of neuromuscular disease-associated proteins in response to eccentric exercise in human skeletal muscle," Journal of Physiology, vol. 543, no. 1, pp. 297-306, 2002.

[153] N. I. Walker, B. V. Harmon, G. C. Gobé, and J. F. Kerr, "Patterns of cell death," Methods and Achievements in Experimental Pathology, vol. 13, pp. 18-54, 1988.

[154] Y. Cheng, E. Gulbins, and D. Siemen, "Activation of the permeability transition pore by Bax via inhibition of the mitochondrial BK channel," Cellular Physiology and Biochemistry, vol. 27, no. 3-4, pp. 191-200, 2011.

[155] M. A. Yenari, J. Liu, Z. Zheng, Z. S. Vexler, J. E. Lee, and R. G. Giffard, "Antiapoptotic and anti-inflammatory mechanisms of heat-shock protein protection," Annals of the New York Academy of Sciences, vol. 1053, pp. 74-83, 2005.

[156] L. M. Dejean, S. Martinez-Caballero, S. Manon, and K. W. Kinnally, "Regulation of the mitochondrial apoptosis-induced channel, MAC, by BCL-2 family proteins," Biochimica et Biophysica Acta, vol. 1762, no. 2, pp. 191-201, 2006.

[157] A. Saleh, S. M. Srinivasula, L. Balkir, P. D. Robbins, and E. S. Alnemri, "Negative regulation of the Apaf-1 apoptosome by Hsp70," Nature Cell Biology, vol. 2, no. 8, pp. 476-483, 2000.

[158] H. M. Beere, B. B. Wolf, K. Cain et al., "Heat-shock protein 70 inhibits apoptosis by preventing recruitment of procaspase- 9 to the Apaf-1 apoptosome," Nature Cell Biology, vol. 2, no. 8, pp. 469-475, 2000.

[159] S. Kelly, Z. J. Zhang, H. Zhao et al., "Gene transfer of HSP72 protects cornu ammonis 1 region of the hippocampus neurons from global ischemia: influence of Bcl-2," Annals of Neurology, vol. 52, no. 2, pp. 160-167, 2002.

[160] E. M. Creagh, R. J. Carmody, and T. G. Cotter, "Heat shock protein 70 inhibits caspase-dependent and -independent apoptosis in Jurkat T cells," Experimental Cell Research, vol. 257, no. 1, pp. 58-66, 2000.

[161] D. D. Mosser, A. W. Caron, L. Bourget, C. Denis-Larose, and B. Massie, "Role of the human heat shock protein hsp70 in protection against stress- induced apoptosis," Molecular and Cellular Biology, vol. 17, no. 9, pp. 5317-5327, 1997.

[162] Z. Zheng, J. Y. Kim, H. Ma, J. E. Lee, and M. A. Yenari, "Anti-inflammatory effects of the $70 \mathrm{kDa}$ heat shock protein in experimental stroke," Journal of Cerebral Blood Flow and Metabolism, vol. 28, no. 1, pp. 53-63, 2008.

[163] D. Tsuchiya, S. Hong, Y. Matsumori et al., "Overexpression of rat heat shock protein 70 is associated with reduction of early mitochondrial cytochrome c release and subsequent DNA fragmentation after permanent focal ischemia," Journal 
of Cerebral Blood Flow and Metabolism, vol. 23, no. 6, pp. 718-727, 2003.

[164] Y. Hayashi, Y. Sawa, N. Fukuyama, H. Nakazawa, and H. Matsuda, "Preoperative glutamine administration induces heatshock protein 70 expression and attenuates cardiopulmonary bypass-induced inflammatory response by regulating nitric oxide synthase activity," Circulation, vol. 106, no. 20, pp. 2601-2607, 2002.

[165] B. Klosterhalfen, C. Töns, S. Hauptmann et al., "Influence of heat shock protein 70 and metallothionein induction by zincbis-(DL-hydrogenaspartate) on the release of inflammatory mediators in a porcine model of recurrent endotoxemia," Biochemical Pharmacology, vol. 52, no. 8, pp. 1201-1210, 1996.

[166] W. Van Molle, B. Wielockx, T. Mahieu et al., "HSP70 protects against TNF-induced lethal inflammatory shock," Immunity, vol. 16, no. 5, pp. 685-695, 2002.

[167] A. S. Baldwin Jr., "The NF- $\kappa$ B and I $\kappa$ B proteins: new discoveries and insights," Annual Review of Immunology, vol. 14, pp. 649-681, 1996.

[168] P. J. Barnes and M. Karin, "Nuclear factor- $\kappa \mathrm{B}$ - a pivotal transcription factor in chronic inflammatory diseases," New England Journal of Medicine, vol. 336, no. 15, pp. 1066-1071, 1997.

[169] S. Ghosh, M. J. May, and E. B. Kopp, "NF- $\kappa$ B and rel proteins: evolutionarily conserved mediators of immune responses," Annual Review of Immunology, vol. 16, pp. 225-260, 1998.

[170] R. Hotchkiss, I. Nunnally, S. Lindquist, J. Taulien, G. Perdrizet, and I. Karl, "Hyperthermia protects mice against the lethal effects of endotoxin," American Journal of Physiology, vol. 265, no. 6, pp. R1447-R1457, 1993.

[171] J. Villar, S. P. Ribeiro, J. B. M. Mullen, M. Kuliszewski, M. Post, and A. S. Slutsky, "Induction of the heat shock response reduces mortality rate and organ damage in a sepsis-induced acute lung injury model," Critical Care Medicine, vol. 22, no. 6, pp. 914-921, 1994.

[172] Y. M. Snyder, L. Guthrie, G. F. Evans, and S. H. Zuckerman, "Transcriptional inhibition of endotoxin-induced monokine synthesis following heat shock in murine peritoneal macrophages," Journal of Leukocyte Biology, vol. 51, no. 2, pp. 181187, 1992.

[173] R. Ran, A. Lu, Zhang et al., "Hsp70 promotes TNF-mediated apoptosis by binding IKK $\gamma$ and impairing NF- $\kappa \mathrm{B}$ survival signaling," Genes and Development, vol. 18, no. 12, pp. 14661481, 2004.

[174] M. C. Arkan, A. L. Hevener, F. R. Greten et al., "IKK- $\beta$ links inflammation to obesity-induced insulin resistance," Nature Medicine, vol. 11, no. 2, pp. 191-198, 2005.

[175] D. Cai, M. Yuan, D. F. Frantz et al., "Local and systemic insulin resistance resulting from hepatic activation of IKK- $\beta$ and NF- $\kappa$ B," Nature Medicine, vol. 11, no. 2, pp. 183-190, 2005.

[176] C. Patel, H. Ghanim, S. Ravishankar et al., "Prolonged reactive oxygen species generation and nuclear factor- $\kappa \mathrm{B}$ activation after a high-fat, high-carbohydrate meal in the obese," Journal of Clinical Endocrinology and Metabolism, vol. 92, no. 11, pp. 4476-4479, 2007.

[177] M. T. Lotze and K. J. Tracey, "High-mobility group box 1 protein (HMGB1): nuclear weapon in the immune arsenal," Nature Reviews Immunology, vol. 5, no. 4, pp. 331-342, 2005.

[178] P. Scaffidi, T. Misteli, and M. E. Bianchi, "Release of chromatin protein HMGB1 by necrotic cells triggers inflammation," Nature, vol. 418, no. 6894, pp. 191-195, 2002.
[179] J. Brett, A. M. Schmidt, S. D. Yan et al., "Survey of the distribution of a newly characterized receptor for advanced glycation end products in tissues," American Journal of Pathology, vol. 143, no. 6, pp. 1699-1712, 1993.

[180] C. Fiuza, M. Bustin, S. Talwar et al., "Inflammation-promoting activity of HMGB1 on human microvascular endothelial cells," Blood, vol. 101, no. 7, pp. 2652-2660, 2003.

[181] U. Senftleben and M. Karin, "The IKK/NF- $\kappa$ B pathway," Critical Care Medicine, vol. 30, no. 1, pp. S18-S26, 2002.

[182] S. Devaraj, M. R. Dasu, S. H. Park, and I. Jialal, "Increased levels of ligands of Toll-like receptors 2 and 4 in type 1 diabetes," Diabetologia, vol. 52, no. 8, pp. 1665-1668, 2009.

[183] S. I. Pachydaki, S. R. Tari, S. E. Lee et al., "Upregulation of RAGE and its ligands in proliferative retinal disease," Experimental Eye Research, vol. 82, no. 5, pp. 807-815, 2006.

[184] S. Hagiwara, H. Iwasaka, A. Hasegawa, H. Koga, and T. Noguchi, "Effects of hyperglycemia and insulin therapy on high mobility group box 1 in endotoxin-induced acute lung injury in a rat model," Critical Care Medicine, vol. 36, no. 8, pp. 2407-2413, 2008.

[185] D. Tang, Y. Shi, L. Jang, K. Wang, W. Xiao, and X. Xiao, "Heat shock response inhibits release of high mobility group box 1 protein induced by endotoxin in murine macrophages," Shock, vol. 23, no. 5, pp. 434-440, 2005.

[186] D. Tang, R. Kang, W. Xiao et al., "Nuclear heat shock protein 72 as a negative regulator of oxidative stress (hydrogen peroxide)-induced HMGB1 cytoplasmic translocation and release," Journal of Immunology, vol. 178, no. 11, pp. 73767384, 2007.

[187] D. Tang, R. Kang, W. Xiao, H. Wang, S. K. Calderwood, and X. Xiao, "The anti-inflammatory effects of heat shock protein 72 involve inhibition of high-mobility-group box 1 release and proinflammatory function in macrophages," Journal of Immunology, vol. 179, no. 2, pp. 1236-1244, 2007. 


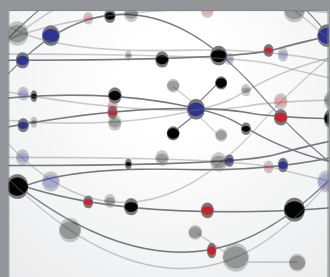

The Scientific World Journal
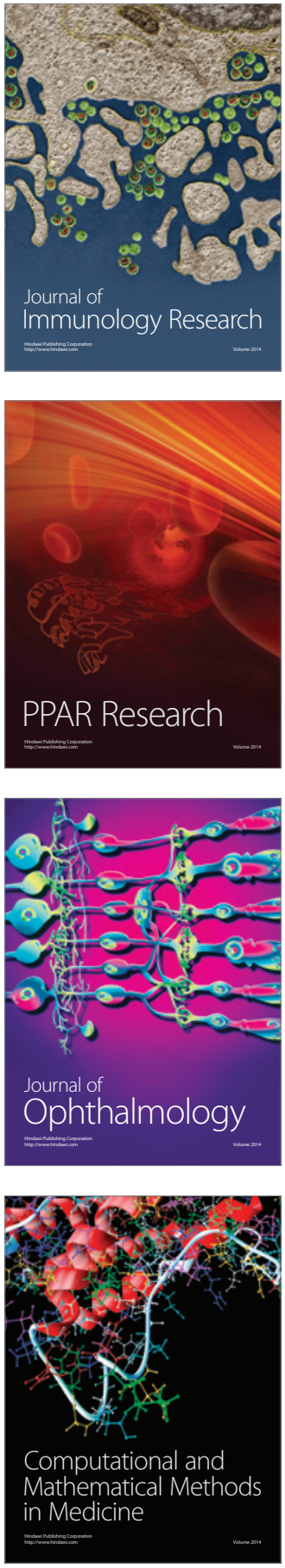

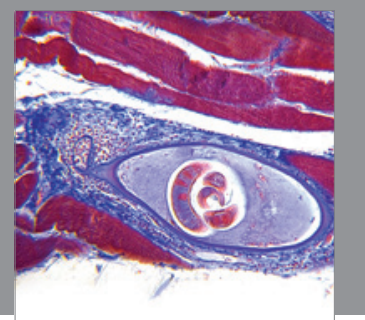

Gastroenterology

Research and Practice
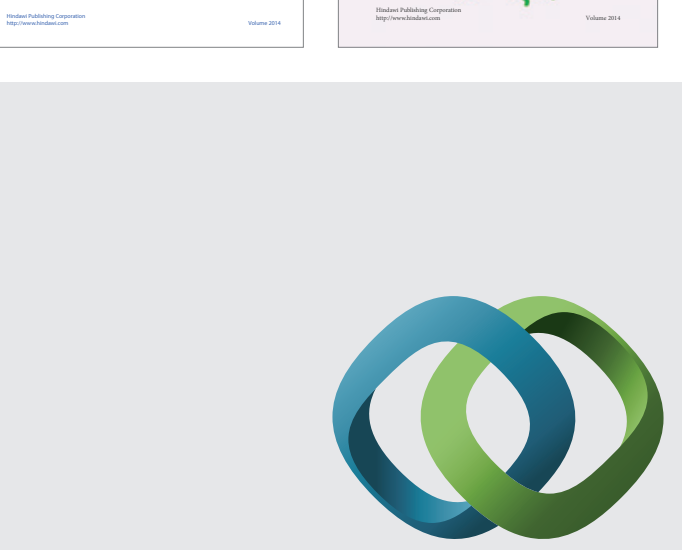

\section{Hindawi}

Submit your manuscripts at

http://www.hindawi.com
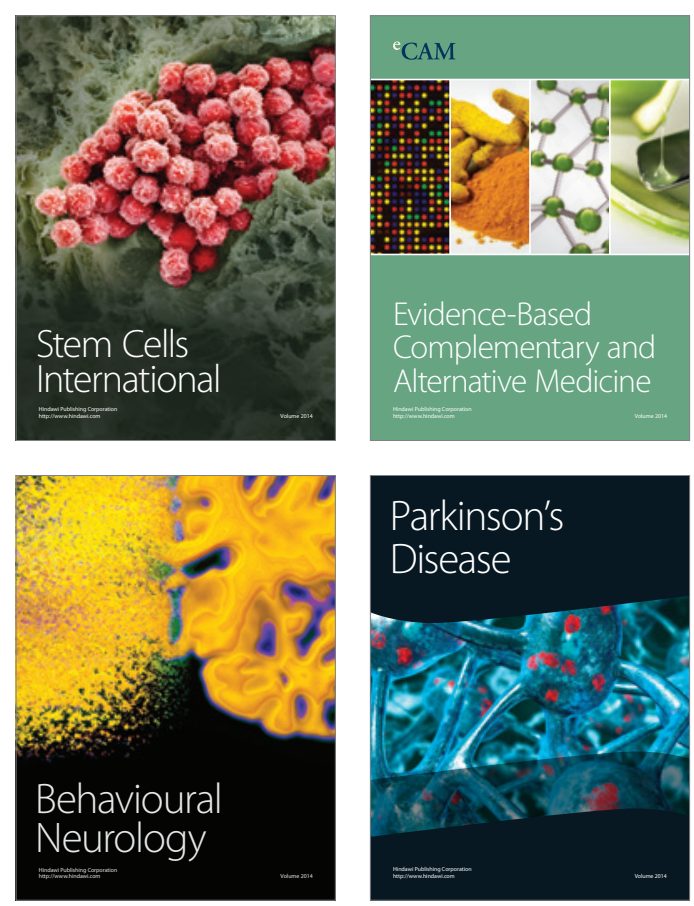

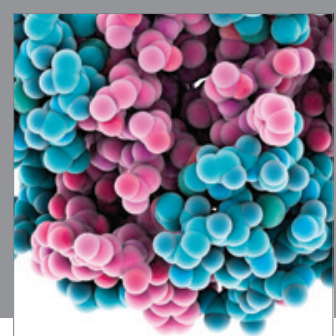

Journal of
Diabetes Research

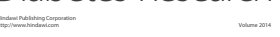

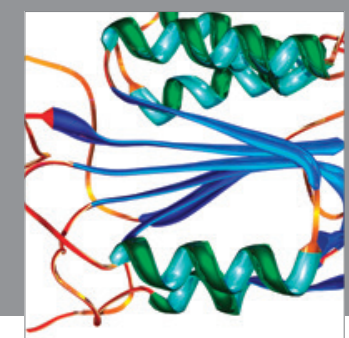

Disease Markers
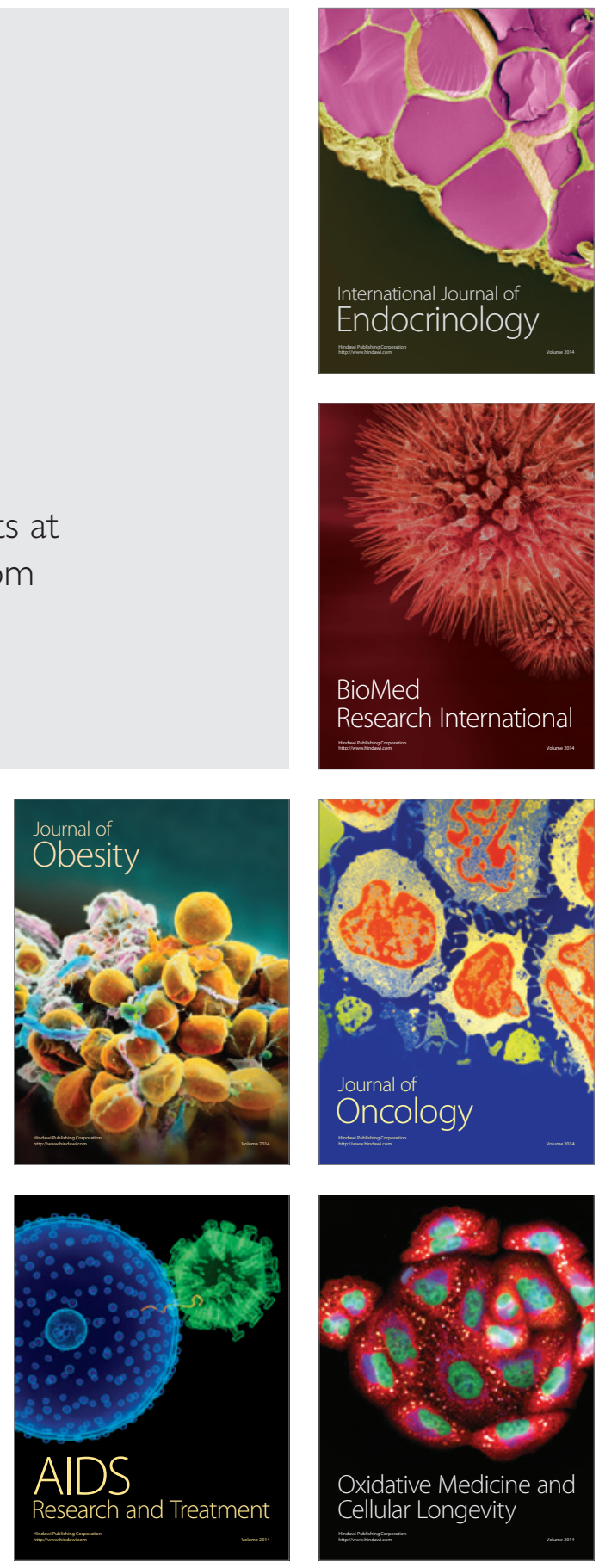